\title{
The COVID-19 crisis and the structural problems of Latin America and the Caribbean: responding to the emergency with a long-term perspective
}

\author{
Martín Abeles, Esteban Pérez Caldentey and Gabriel Porcile ${ }^{1}$
}

\begin{abstract}
The economies of Latin America and the Caribbean have been slipping behind in the global economy, weighed down by structural problems that hinder their capacity to grow and absorb technology. The coronavirus disease (COVID-19) pandemic has not only brought these structural problems into sharper relief, but has also exacerbated them, by reinforcing adverse trends in growth, employment and income distribution. This article analyses these trends and argues that the crisis requires a response that is both immediate but also aims to overcome long-term constraints. Very robust fiscal policies are needed to sustain aggregate demand; and such policies need a substantial investment component aimed at building technological capacities, increasing diversification and strengthening linkages in the production matrix.
\end{abstract}

\section{Keywords}

COVID-19, virus, epidemics, economic aspects, economic crisis, economic growth, employment, income distribution, investments, monetary policy, fiscal policy, Latin America and the Caribbean

JEL classification

O33, 040,041

Authors

Martín Abeles is Chief of the Economic Commission for Latin America and the Caribbean (ECLAC) Office in Buenos Aires. Email: martin.abeles@cepal.org.

Esteban Pérez Caldentey is Chief of the Financing for Development Unit in the Economic Development Division of ECLAC. Email: esteban.perez@cepal.org.

Gabriel Porcile is an Economic Affairs Officer in the Division of Production, Productivity and Management of ECLAC. Email: jose.porcile@cepal.org.

1 The opinions expressed herein are the authors' own and may not coincide with those of ECLAC. 


\section{Introduction}

The coronavirus disease (COVID-19) crisis hit Latin America and the Caribbean with exceptional virulence. Not only will the region experience the largest contraction of all developing economies in 2020, but it is also expected to stage the weakest recovery. The pandemic has devastated the region during one of the slowest growth periods in its history.

The commodities trade boom - which lasted practically throughout 2004-2013, aside from a jolt in 2009 - fuelled growth in the regional economy and enabled the share of formal employment to expand (which, in conjunction with redistributive policies, helped to improve the income distribution, which was extremely unequal by global standards). Since 2014, however, growth in the Latin American economy has faltered, and progress in the fight against poverty and inequality has been interrupted. ${ }^{2} \mathrm{~A}$ key factor in this stagnation has been the persistence of a pattern of production and export specialization that is concentrated in lower-technology goods and services. This is juxtaposed by an international technology frontier that is moving ever faster, thus accentuating the technology gap in the region.

Backdropped by these structural problems, the COVID-19 crisis is devastating the region and requires urgent action by governments and public policy. The question that arises is to how to transform this emergency and the new role of policies into an instrument that responds to the pandemic but also facilitates an economic transformation based on overcoming these structural problems. This article argues that, in order to sustain effective demand and employment - which have been ravaged by the pandemic - the response needs to be more than immediate and large-scale; it should also reflect a long-term perspective and promote changes in the production structure and build technological capacities. This perspective calls into question the effectiveness of both monetary and fiscal policy transmission mechanisms, in fulfilling that task. The long-term analysis emphasizes the links between fiscal policy, structural change, and overcoming external constraints on growth. The response must involve building a new style of development, rather than restoring a pattern that was showing clear signs of exhaustion before the pandemic broke out.

Section II of this article explains that the Latin America and the Caribbean region will experience both the sharpest contraction in the developing world and the least dynamic recovery. Based on this evidence, it argues that the impact of COVID-19 on Latin America and the Caribbean is explained through the region's structural constraints.

Section III argues that these conditioning factors, in conjunction with others such as the region's considerable financial openness, diminish the response capacity of countercyclical macroeconomic policy - both fiscal, but especially monetary. In fact, in a context of financial openness, with highly concentrated income and wealth, and a production base that is limited and, in some cases, reprimarized, monetary policy transmission mechanisms can work in the opposite direction to that postulated by conventional economic theory. These same factors reduce the effectiveness of fiscal policy transmitted through the multiplier, and they alter the dynamics of public debt and its sustainability over time. This section argues that the sine qua non condition for stabilizing the debt is to underpin economic growth.

In the longer term, to boost growth on a sustainable basis, investment needs to be targeted on building capacities that alleviate the external constraint. This reinforces the message conveyed in the different sections of this article, namely the need to base the recovery on interactions between fiscal policy, investment policy, the revival of effective demand and employment, and structural change. Drawing on the foregoing analysis, sections IV and $V$ analyse the links between investment, fiscal policy and growth, constrained by the specialization pattern in an economy that does not issue the international

\footnotetext{
2 Another very important structural issue is the global environmental crisis and its manifestations and effects in Latin America and the Caribbean -the analysis of which goes beyond the scope of this article. On this subject, see ECLAC (2020a).
} 
reserve currency and relies excessively on short-term financing, as is the case in Latin America and the Caribbean. This situation can fuel increased borrowing on international credit markets to finance the external transactions demanded by the region's growth. It can therefore be concluded that the sustainability of the public debt - that is, economic growth - is ultimately inextricably linked to overcoming the external constraint. Lastly, section VI sets forth the main conclusions.

\section{Why has the COVID-19 crisis had such a heavy impact on Latin America and the Caribbean?}

The pandemic has hit the region with particular virulence. The available evidence shows that Latin America and the Caribbean will be the developing region with the sharpest contraction in 2020. As figure 1 shows, the regional economy is expected to shrink by $9.1 \%$ - much more than the contractions projected for Europe, the Middle East and Central Asia, Sub-Saharan Africa and Asia, of 4.6\%, $4.1 \%, 3.0 \%$ and $1.7 \%$, respectively.

Figure 1

Selected developing regions: gross domestic product (GDP) growth rates, 2019-2025

(Percentages)

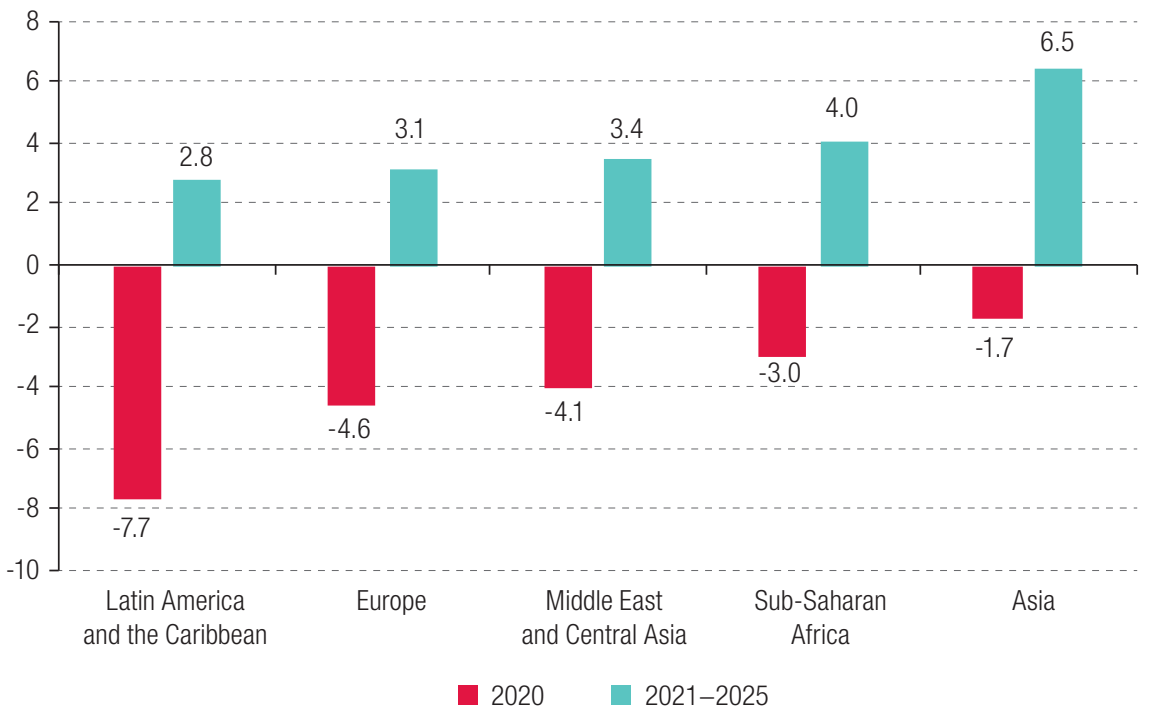

Source: International Monetary Fund (IMF), World Economic Outlook, Washington, D.C., October 2020; Economic Commission for Latin America and the Caribbean (ECLAC), Preliminary Overview of the Economies of Latin America and the Caribbean, 2020 b (LC/PUB.2020/17-P), Santiago, 2020.

Note: The growth estimate for 2020 has been obtained from ECLAC. Estimates for the period 2021-2015 are from the International Monetary Fund (IMF).

This suggests that the impact of the pandemic crisis could be as regressive and as long-lasting as the debt crisis of the early 1980s, owing to three interrelated phenomena: the region's anaemic growth in earlier years, the heterogeneity of its production structure and the unequal distribution of its income and wealth. 


\section{The pre-COVID-19 situation: sluggish growth and investment}

Before the health crisis, economic growth in the region was already meagre. Data for 1991-2019 show that, following a V-shaped recovery from the global financial crisis in 2010 and, especially, since the collapse of international commodity prices, both regional and subregional growth rates have been declining. In 2011-2019, Latin America and the Caribbean recorded its lowest growth rate since the 1950s (ECLAC, 2020a). The subregional data available for South and Central America and Mexico in 1991-2019 display a similar trend. In South America, GDP growth averaged 2.8\% in 1991-2002, 4.4\% in 2002-2008 and 0.9\% in 2011-2019; and the equivalent rates in Central America and Mexico were 3.3\%, 2.5\% and 3.0\%, respectively. The comparison between the years of surging international commodity prices (2004-2008) and the period since their collapse (2014-2019) reflects this trend eloquently, especially in the South American countries.

This growth slowdown was not confined to the countries of South America. In 2014-2019, nine of the 12 Caribbean countries grew more slowly than in the previous period (2004-2008); and, in three of these (Dominica, Suriname and Trinidad and Tobago), GDP actually shrank. In both Central America and Mexico, as well as in South America, all economies grew more slowly in 2014-2019 than in the earlier 2004-2008 period. In South America, three major economies - Argentina, the Bolivarian Republic of Venezuela and Brazil - saw their activity levels decline in the five-year period prior to COVID-19. However, as shown in figure 2, even when these countries are excluded, South America's growth between 2014-2019, at 2.6\% was less than half of the 5.5\% recorded in 2004-2008.

Figure 2

Latin America and the Caribbean: GDP growth by subregion, 2004-2008 and 2014-2019

(Simple average, percentages)

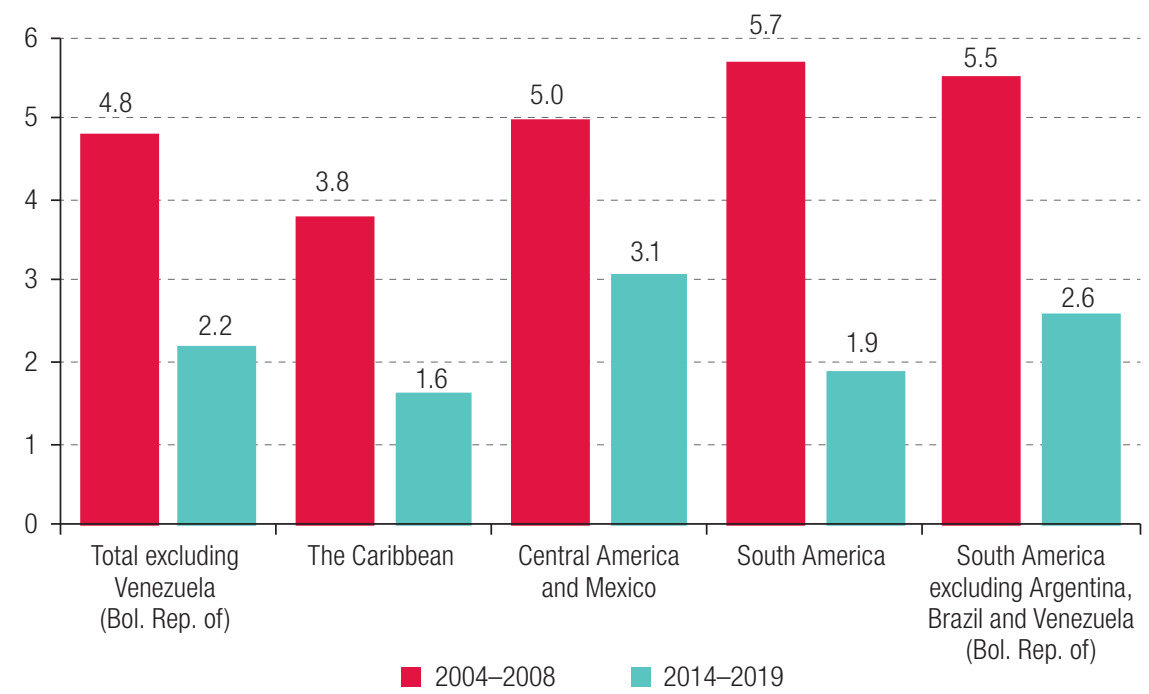

Source: Prepared by the authors, on the basis of data from the Economic Commission for Latin America and the Caribbean (ECLAC). Note: Central America and Mexico includes Costa Rica, Cuba, the Dominican Republic, El Salvador, Honduras, Mexico, Nicaragua and Panama. South America includes Argentina, Brazil, Chile, Colombia, Ecuador, Paraguay and the Plurinational State of Bolivia. Caribbean countries include Barbados, Bahamas, Belize, Jamaica, Saint Lucia and Trinidad and Tobago.

In the pre-pandemic period, the region's growth was also sluggish compared to that of other developing regions. For example, the developing countries in Asia grew by $4.5 \%$ in $2014-2019$, outpacing all subregions of Latin America and the Caribbean. Of the 30 developing economies in Asia, 26 expanded by more than Latin America and the Caribbean. The region's growth was also lower than 
that of the developing countries of Europe, where activity levels grew by $2.8 \%$ per year on average between 2014 and 2019, with 13 of the 16 countries in question expanding by more than the 2.3\% average for Latin America and the Caribbean in that period.

The region's lacklustre growth had a negative impact on the investment rate. This is not surprising, because it reflects the importance of the accelerator effect on investment decisions, as discussed in greater detail below. An analysis by the Economic Commission for Latin America and the Caribbean (ECLAC) of the determinants of investment in 1995-2017 in six of the region's countries (Argentina, Brazil, Chile, Colombia, Mexico and Peru) shows that the index of economic activity is the key determinant of investment. ${ }^{3}$

This slowdown in the expansion of the capital stock made it difficult to overcome the structural problems that are at the root of the 2014-2019 slowdown: without investment, it is impossible to transform specialization patterns and thus alleviate the external constraint (see section IV). In South America (excluding the Bolivarian Republic of Venezuela), the investment rate fell from 23.4\% of GDP in 2013 to 20.5\% in 2019. If Argentina and Brazil (the countries with the worst relative performance at that time) are also excluded, the investment rate is still down by more than 2 percentage points (from $24.4 \%$ to $21.9 \%$ in the same period). In the case of Central America and Mexico and the Caribbean, the average investment rate also slipped from over 26\% of GDP to just over 22\% (see figure 3).

The region's anaemic economic growth explains why the rate of growth of investment declined for four consecutive years $(-2.1 \%$ in $2014,-4.5 \%$ in $2015,-5.2 \%$ in 2016 and $-0.2 \%$ in 2017). This, in turn, undermined job creation, especially in South America, where the average unemployment rate rose from 5.8\% in 2013 to $7.6 \%$ in 2019 (see figure 4). Joblessness increased during the same period in eight of the nine South American countries for which data is available and in three cases (Argentina, Brazil and Uruguay) the unemployment rate rose by more than two percentage points. In Central America and Mexico and the Caribbean, the unemployment rate behaved unevenly: rising in four of the 15 economies for which data are available.

Figure 3

Latin America and the Caribbean: investment rate, by subregion, 2004-2019 (Simple average, percentages)

\section{A. South America}

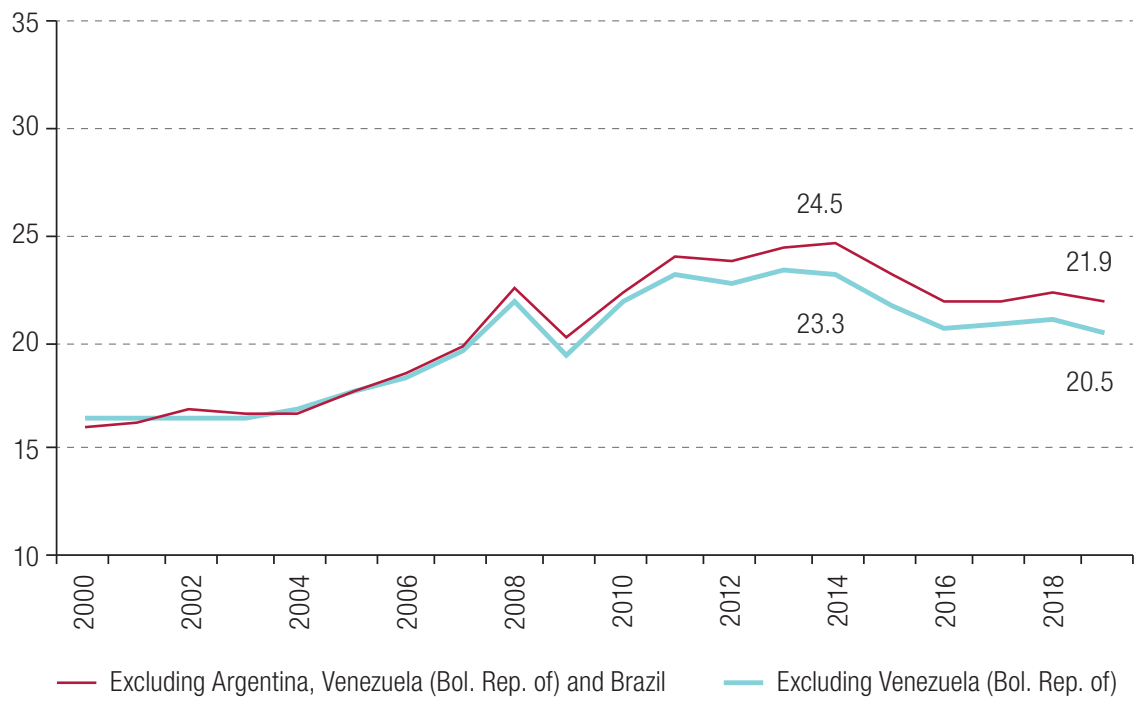

\footnotetext{
3 The other variables considered include the domestic monetary-policy rate, the external interest rate, commodity prices, the real exchange rate, and a risk indicator (the Emerging Market Bond Index (EMBI)). See ECLAC (2018).
} 
Figure 3 (concluded)

B. Central America, Mexico and the Caribbean

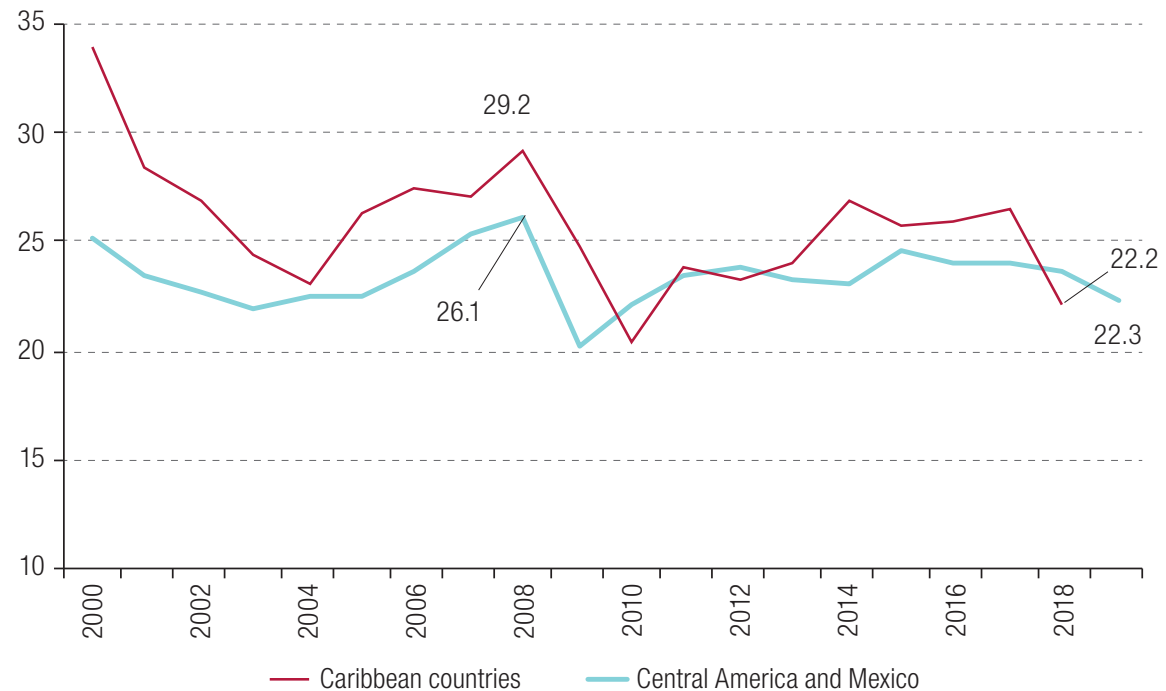

Source: Prepared by the authors, on the basis of Economic Commission for Latin America and the Caribbean (ECLAC), CEPALSTAT [online database] http://estadisticas.cepal.org/cepalstat/portada.html?idioma=english.

Note: Central America and Mexico includes Costa Rica, Cuba, El Salvador, Honduras, Mexico, Nicaragua, Panama and Dominican Republic. South America includes Argentina, Brazil, Chile, Colombia, Ecuador, Paraguay and the Plurinational State of Bolivia. Caribbean countries include Barbados, Bahamas, Belize, Jamaica, Saint Lucia and Trinidad and Tobago.

\section{Figure 4}

Latin America and the Caribbean (21 countries): unemployment rate, by subregion, 2000-2019 (Simple average, percentages)

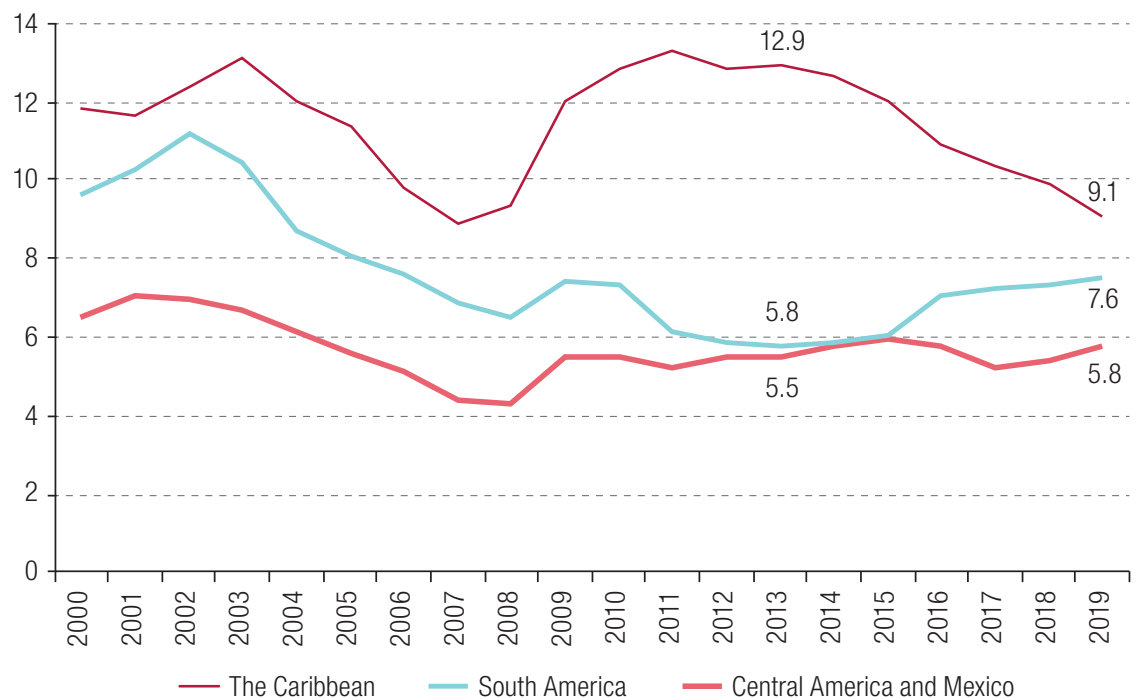

Source: Prepared by the authors, on the basis of Economic Commission for Latin America and the Caribbean (ECLAC), CEPALSTAT [online database] http://estadisticas.cepal.org/cepalstat/portada.html?idioma=english.

Note: Central America and Mexico includes Costa Rica, Cuba, El Salvador, Honduras, Mexico, Nicaragua, Panama and Dominican Republic. South America includes Argentina, Brazil, Chile, Colombia, Ecuador, Paraguay and the Plurinational State of Bolivia. Caribbean countries include Barbados, Bahamas, Belize, Jamaica, Saint Lucia and Trinidad and Tobago.

In South America, the deterioration of conditions on the labour market, combined with a slight increase in inequality, interrupted (and in some cases partially reversed) the declining trend of poverty that had been under way since the early years of the 2000 decade. In 2014-2019, after several years 
of uninterrupted reduction, the average poverty rate in South America (excluding the Bolivarian Republic of Venezuela) plateaued between $16 \%$ and $17 \%$. By contrast, in Central America and Mexico, despite the growth slowdown, the decreasing trend in the poverty rate did not reverse until the outbreak of the pandemic (see figure 5). The relative deterioration of incomes among the poorest households, which directly detracts from the buoyancy of private consumption, generated negative feedback with the other factors that were undermining aggregate demand (the drop in export earnings and the fall in investment expenditure). This negative relationship between income distribution, poverty and aggregate demand also played a key role in the pandemic crisis.

\section{Figure 5}

South America: poverty rate, 2000-2019

(Simple average, percentages)

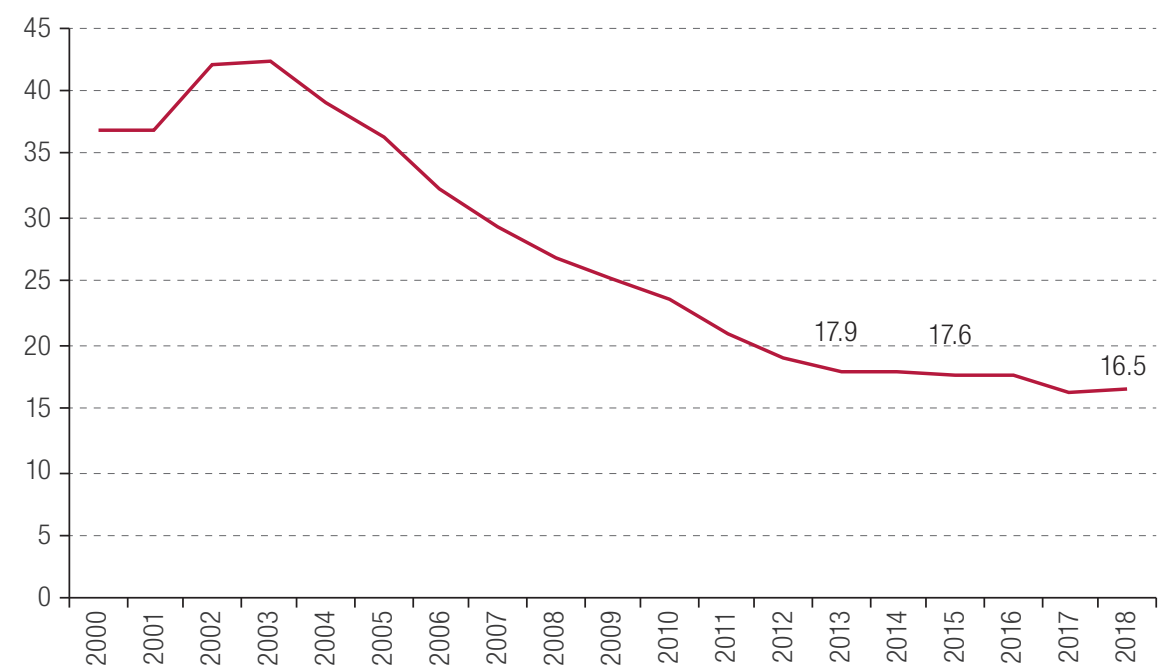

Source: Prepared by the authors, on the basis of Economic Commission for Latin America and the Caribbean (ECLAC), CEPALSTAT [online database] http://estadisticas.cepal.org/cepalstat/portada.html?idioma=english.

Note: The series correspond to poverty rates estimated according to ECLAC methodology, and may differ from the estimates published by each country's national statistical institute. The indicator does not include the Bolivarian Republic of Venezuela.

\section{Structural deficiencies underlying weak economic growth}

The economic slowdown in the years prior to the pandemic was associated with a number of, practically endemic, structural weaknesses that rendered the region more vulnerable to an adverse international economic context, despite liquidity abundance.

First, the heavy weight of primary products in the region's export basket, especially in South America, but also in several Caribbean countries, meant that the fall in international commodity prices since 2014 worsened the terms of trade. This reduced momentum on the demand side and also diminished external room for manoeuvre as the region's foreign-exchange earnings declined. Between 2013 (the year before the collapse of international commodity prices) and 2019 , average international metal prices fell by $12 \%$, while agricultural prices shed $17 \%$ and oil prices plummeted by $35 \%$.

Second, specialization in primary sector production, together with weak intraregional production and trade linkages, meant that the slower growth in world trade and the advance of extraregional trading relations had a significant impact on Latin America and the Caribbean. In fact, the region's export growth, measured in constant prices, slowed more sharply than world trade as a whole. This shows that the export slowdown was due not only to slackening world trade, but also to reductions in the income elasticity of the region's exports, which fell in most cases. 
Between 2000-2008 and 2010-2018, the income elasticity of exports fell in six of the eight South American countries for which it had been estimated. In the case of Central America and Mexico, it fell in three of the five countries analysed (see table 1). This dynamic was not matched by a similar change in the income elasticity of imports, which also declined in several of these countries, but less steeply. As noted in section IV, the pre-pandemic growth slowdown in 2015-2019 is explained partly by a fall in the ratio between import and export elasticities which, in conjunction with the rate of global growth, determines the growth rate that is compatible with long-term external balance.

Table 1

Latin America and the Caribbean (13 countries): foreign trade elasticities, 2000-2018

\begin{tabular}{|c|c|c|c|c|c|c|c|c|c|}
\hline & & \multicolumn{2}{|c|}{$\begin{array}{l}\text { Income elasticity } \\
\text { of exports }\end{array}$} & \multicolumn{2}{|c|}{$\begin{array}{l}\text { Income elasticity } \\
\text { of imports }\end{array}$} & \multicolumn{2}{|c|}{$\begin{array}{l}\text { Difference between } \\
\text { elasticities }\end{array}$} & \multicolumn{2}{|c|}{ Ratio of elasticities } \\
\hline & & $\begin{array}{c}2000- \\
2008\end{array}$ & $\begin{array}{c}2010- \\
2018\end{array}$ & $\begin{array}{c}2000- \\
2008\end{array}$ & $\begin{array}{c}2010- \\
2018\end{array}$ & Exports & Imports & $\begin{array}{c}2000- \\
2008\end{array}$ & $\begin{array}{c}2010- \\
2018\end{array}$ \\
\hline \multirow[t]{8}{*}{ South America } & Argentina & 1.5 & 0 & 2.5 & 2.6 & -1.5 & 0 & 0.6 & 0 \\
\hline & Bolivia (Plurinational State of) & 2.1 & 2.3 & 1.8 & 1.2 & 0.2 & -0.6 & 1.2 & 1.9 \\
\hline & Brazil & 2.4 & 0.4 & 1.3 & 2.8 & -1.9 & 1.4 & 1.8 & 0.2 \\
\hline & Chile & 0.9 & 0.1 & 2.2 & 0.6 & -0.8 & -1.6 & 0.4 & 0.2 \\
\hline & Colombia & 1.6 & 0.9 & 2.1 & 1.4 & -0.8 & -0.7 & 0.8 & 0.6 \\
\hline & Ecuador & 1.9 & 1.3 & 1.8 & 0.8 & -0.6 & -1.0 & 1.1 & 1.6 \\
\hline & Paraguay & 1.6 & 2.6 & 2.2 & 0.8 & 1.0 & -1.4 & 0.7 & 3.1 \\
\hline & Peru & 2.6 & 0.9 & 1.7 & 0.8 & -1.6 & -0.9 & 1.6 & 1.2 \\
\hline \multirow{5}{*}{$\begin{array}{l}\text { Central America } \\
\text { and Mexico }\end{array}$} & Costa Rica & 2.2 & 2.2 & 1.2 & 1.3 & 0 & 0.1 & 1.8 & 1.7 \\
\hline & Guatemala & 1.0 & 0.6 & 0.6 & 1.2 & -0.4 & 0.5 & 1.7 & 0.5 \\
\hline & Honduras & 2.1 & 1.6 & 1.5 & 0.9 & -0.5 & -0.6 & 1.4 & 1.8 \\
\hline & Mexico & 1.7 & 2.3 & 2.0 & 1.8 & 0.7 & -0.2 & 0.8 & 1.3 \\
\hline & Nicaragua & 3.4 & 2.7 & 1.8 & 1.1 & -0.7 & -0.7 & 1.9 & 2.5 \\
\hline
\end{tabular}

Source: Prepared by the authors on the basis of data from the World Bank, International Monetary Fund (IMF) and Economic Commission for Latin America and the Caribbean (ECLAC), CEPALSTAT [online database] http://estadisticas.cepal.org/ cepalstat/portada.html?idioma=english.

Note: The income elasticity of exports was estimated by the authors using the weighted GDP of trading partners and a relative price indicator calculated as the ratio between the implicit price deflators of exports and GDP, respectively. The income elasticity of imports was estimated considering each country's GDP and a relative price indicator calculated as the ratio between the implicit price deflators of imports and GDP, respectively. The estimates were made by ordinary least squares with logarithmic variables.

Declining terms of trade and weaker export growth (in volume terms) eroded the external accounts and generated a widening current account deficit. In South America, the current account surplus of 1.5\% of GDP recorded in 2004-2008 became a deficit of 2.1\% in 2014-2019, despite the slower pace of overall expansion (see figure 6). In South America, all countries saw their current account balances deteriorate. In the Caribbean and in Central America and Mexico, by contrast, the current account deficit narrowed as a result of rapid growth in the United States, the subregion's main trading partner. The only countries in these subregions in which the current account deficit deteriorated were the Bahamas, Guyana, Mexico, Panama, Suriname, and Trinidad and Tobago.

The regional growth slowdown would have been even greater, were it not for the fact that most of the region's countries had ample, low-cost access to international financial markets. In South America, private sector external debt, expressed as a percentage of current account inflows (which reflects external repayment capacity) grew from $95 \%$ in 2013 to $124 \%$ in 2019 , while the equivalent figure for public external debt rose from $52 \%$ to $91 \%$ in the same period. In particular, private external debt increased sharply in Brazil, Chile and Colombia, and public external debt grew in Argentina, Colombia and the Plurinational State of Bolivia. In Central America and Mexico, during the same period, private sector external debt increased from $82 \%$ to $90 \%$ of current account inflows, while the public sector external debt grew from $52 \%$ to $62 \%$ (see figure 7 ). 


\section{Figure 6}

Latin America and the Caribbean (21 countries): current account balance, 2000-2018

(Simple average, percentage of GDP)

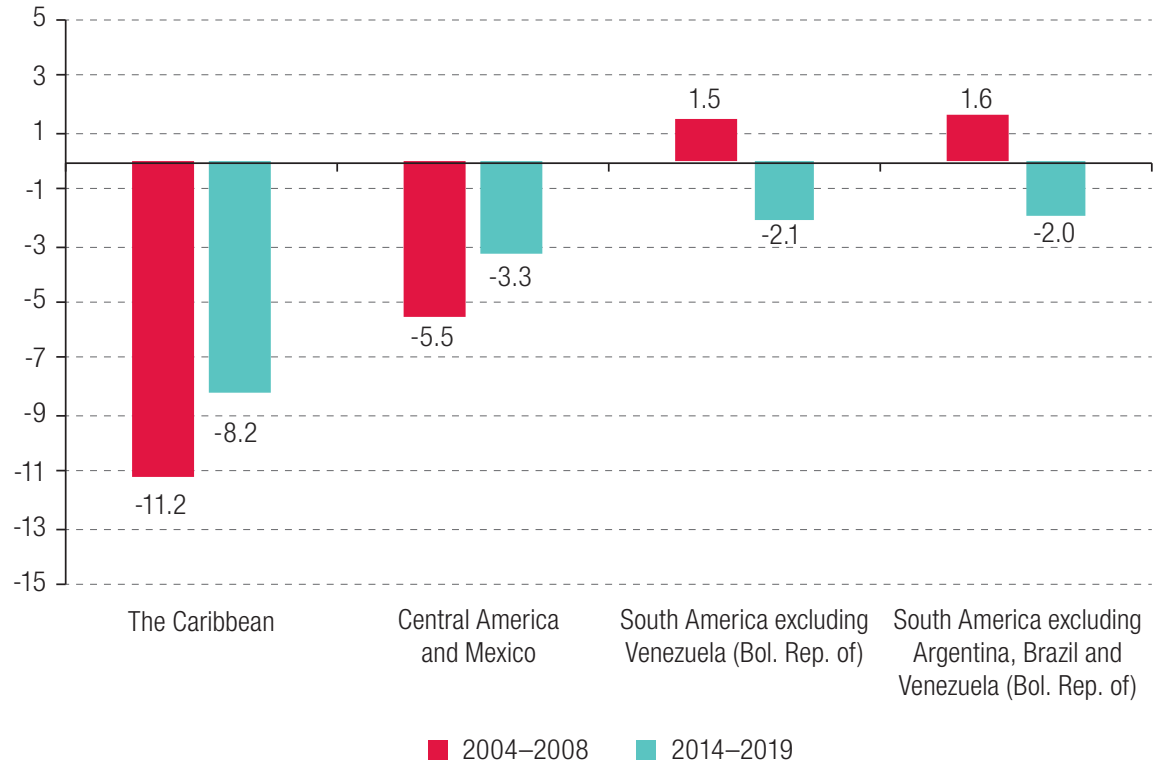

Source: Prepared by the authors, on the basis of Economic Commission for Latin America and the Caribbean (ECLAC), CEPALSTAT [online database] http://estadisticas.cepal.org/cepalstat/portada.html?idioma=english.

Note: Central America includes Costa Rica, El Salvador, Guatemala, Haiti, Honduras, Nicaragua, Panama and Dominican Republic. Caribbean countries include Antigua and Barbuda, Bahamas, Barbados, Belize, Dominica, Grenada, Guyana, Jamaica, Saint Kitts and Nevis, Saint Vincent and the Grenadines, Saint Lucia, Suriname, and Trinidad and Tobago.

Figure 7

Latin America (15 countries): external debt, 2005-2019

(Simple average, percentage of current account inflows)

\section{A. South America}

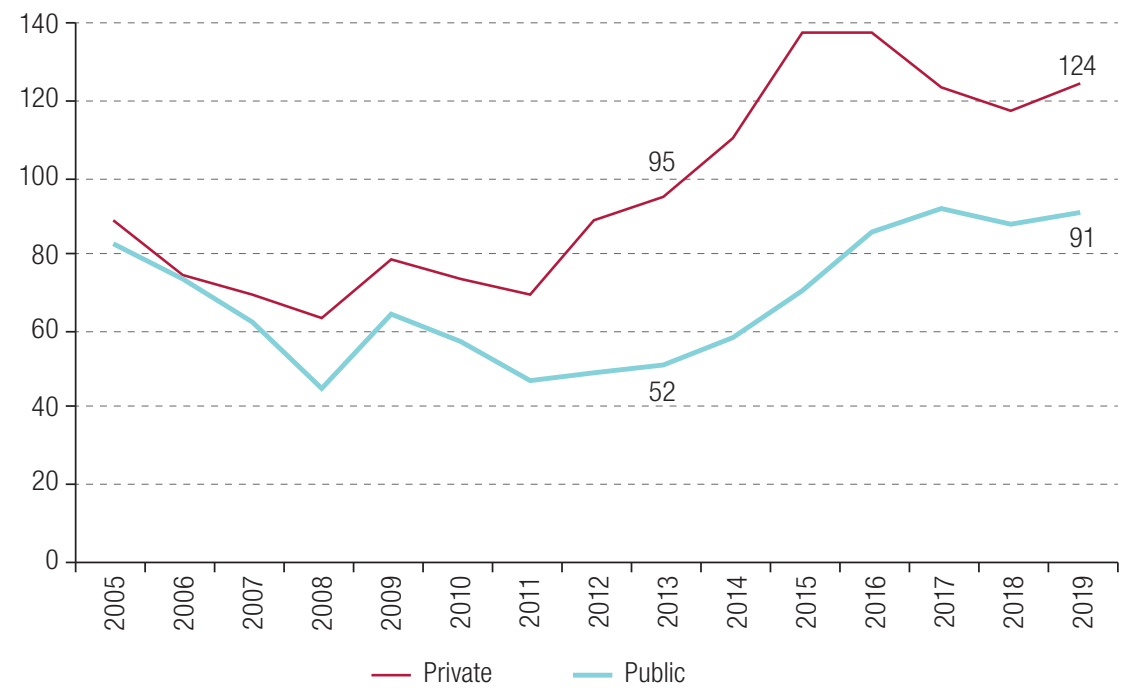


Figure 7 (concluded)

\section{B. Central America and Mexico}

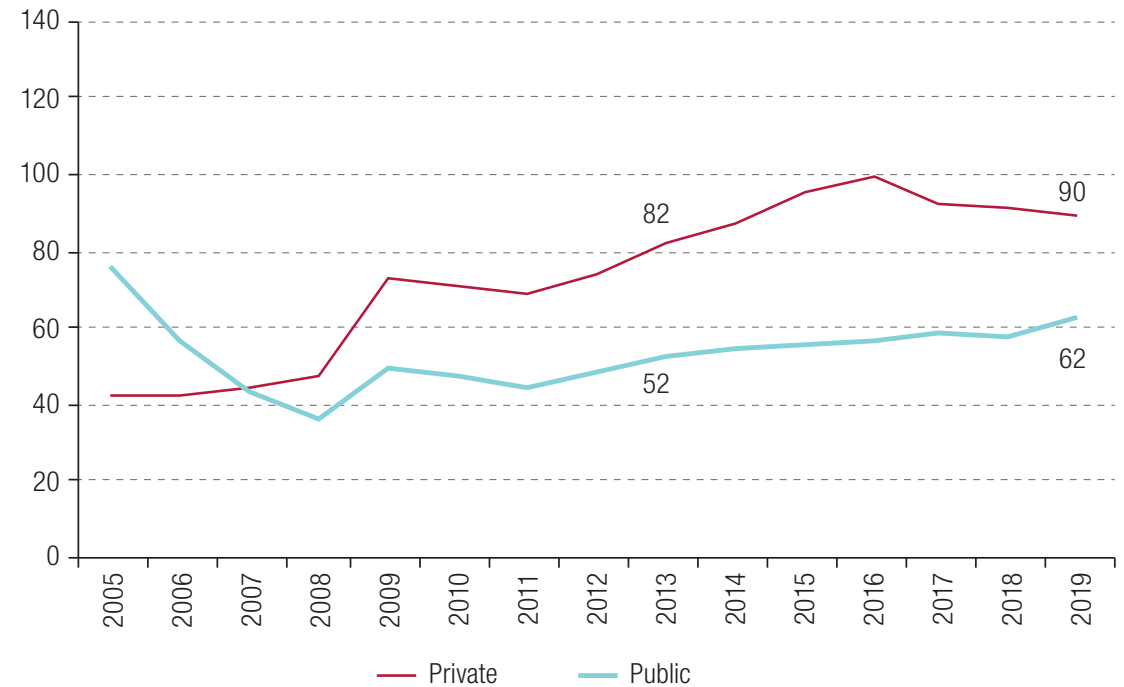

Source: Prepared by the authors, on the basis of data from the International Monetary Fund (IMF).

Note: South America includes Argentina, Brazil, Chile, Colombia, Ecuador, the Plurinational State of Bolivia and Uruguay. Central America includes: Costa Rica, El Salvador, Guatemala, Honduras, Nicaragua, Panama and Dominican Republic.

The increase in external debt entailed higher interest charges, which aggravated the scarcity of foreign exchange owing to the structural constraints mentioned above (reprimarization). In South America, this type of expenditure grew from 4.5\% of current account inflows in 2012 to $10.4 \%$ in 2018; and, in the case of Central America, it went from $2.9 \%$ to $4.6 \%$ in the same period (see figure 8 ).

\section{Figure 8}

Latin America (12 countries): interest payments on foreign debt, 2005-2018 (Simple average, percentage of current account inflows)

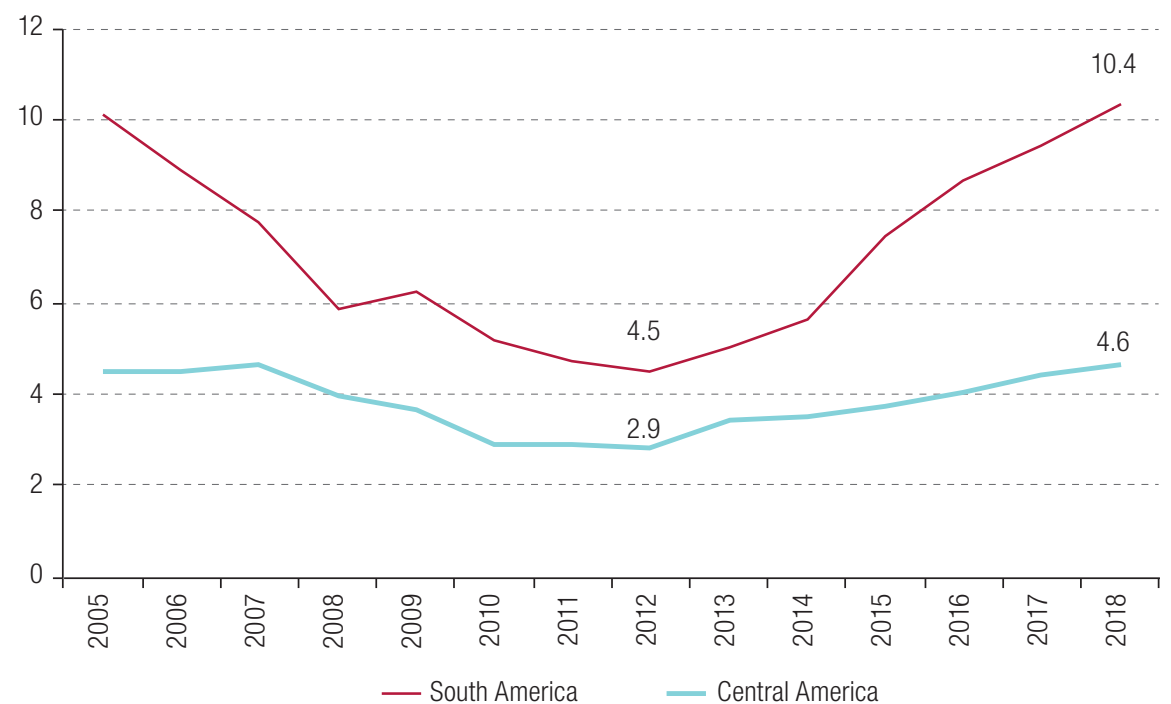

Source: Prepared by the authors, on the basis of data from the International Monetary Fund (IMF).

Note: South America includes Argentina, Brazil, Chile, Colombia, Ecuador, the Plurinational State of Bolivia and Uruguay. Central America includes Costa Rica, El Salvador, Guatemala, Honduras and Dominican Republic. 
The region's weak performance in the years prior to the pandemic was the result of a set of structural deficiencies that generated negative feedback through a variety of channels. First, weak exports reduced the capacity to sustain faster growth, which in turn undermined the process of capital formation and, given the reduced availability of foreign currency, forced the region's economies to resort increasingly to external financing. The lack of linkage between external borrowing processes and the transformation of local production structures (due, among other things, to the weakness of industrial policies in the region) tended to accentuate external vulnerability in the medium term. In several cases, this reduced the scope for accessing additional external financing during the initial stages of the pandemic, as Latin America and the Caribbean (like most developing countries) faced significant capital outflows.

In the later stages of the pandemic this trend has reversed, as the expansionary monetary policies of the major central banks of developed countries, and in particular of the Federal Reserve of the United States, fostered a search for yield by private investors in emerging market economies, including in those of Latin America and the Caribbean. The counterpart of this trend is an unprecedented build-up of debt. As things stand, Latin America and the Caribbean is the most indebted region of the developing world with $80 \%$ of general government debt relative to GDP (IMF, 2020b). This not only limits the scope for countercyclical fiscal policy, but could also lead to financial fragility and instability. Also, in the case of some countries of the region (in particular the smaller ones) the rates of interest on debt exceed the historical and projected rates of growth, raising sustainability concerns. Overall, it seems that increased access to international capital markets can reinforce, rather than ease, the external constraint.

The high degree of structural heterogeneity, which in recent years has been exacerbated by the growing share of the primary sector and restricts long-term growth capacity, has amplified the internal shock and in the case of some economies (the smaller ones) the external shock of the pandemic domestically. Such heterogeneity can be discerned in many sectors of low productivity and high levels of labour informality. These are associated with the provision of services in urban areas, which, as the virus spread, left much of the population without income. In most of the region's countries, more than half of all non-farm workers are informal; and in some cases three quarters of all persons employed work informally (see figure 9).

Figure 9

Latin America and the Caribbean (15 countries): labour informality in the non-agricultural sector, 2015-2019

(Percentages)

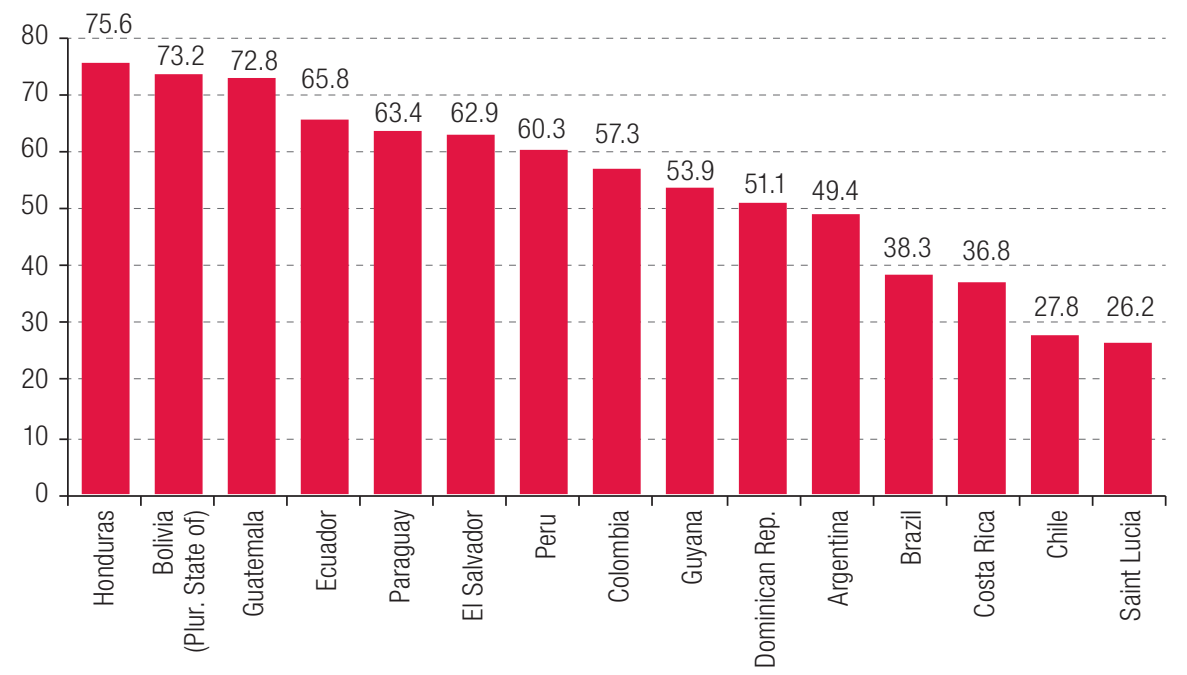

Source: Prepared by the authors, on the basis of data from the International Labour Organization (ILO).

Note: The figures shown represent the latest available data. Those for Argentina, Chile, Colombia, Costa Rica, the Dominican Republic, Ecuador, Paraguay, Peru, the Plurinational State of Bolivia and Saint Lucia refer to 2019; data from Brazil correspond to 2015; data from Guatemala and Honduras are for 2017; and data from Guyana and El Salvador refer to 2018. 


\section{Challenges in managing countercyclical policy}

A contraction as sharp as that experienced by the Latin American economy in 2020 (-7.7\%) (ECLAC, 2020b), caused by the impact of COVID-19 on the region's economic and social fabric and compounded by social distancing policies, requires a monetary and fiscal countercyclical response. ${ }^{4}$

However, the implementation of countercyclical policy, whether monetary or fiscal, to boost aggregate demand, cannot be assumed, nor can its effectiveness. In the peripheral economies, which includes those of Latin America and the Caribbean, transmission mechanisms (the process through which economic policy decisions are transmitted through changes in nominal or financial and real variables) do not function smoothly; and they may well produce results that are the opposite of those expected.

The region's economies are characterized by a high degree of openness and financial integration, but also external dependency. This is reflected in their exposure to the liquidity cycle of the central countries and to fluctuations in international commodity prices. These specific features make the financial channel of the exchange rate a key monetary policy transmission mechanism, since it can counteract the effects of the monetary policy channels envisaged in monetary theory. ${ }^{5}$

Monetary policy is rendered even less effective by some of the region's structural features, which also affect peripheral economies in general. These include imperfect substitution between local currencies and international reserve currencies; and the high concentration of income and, more importantly, wealth, which hinders the key objective of countercyclical policy in the downswing phase of the business cycle, namely to boost aggregate demand.

As analysed below, the region's structural characteristics also weaken the multiplier, which is the main transmission mechanism in the case of fiscal policy. It should also be noted that the adjustment policies implemented in the 1980s and 1990s under the Washington Consensus, have led to reduced public sector investment. These policies were inspired by an orthodox view that doubts the effectiveness of fiscal policy, which has prevailed ever since. ${ }^{6}$ Moreover, as a "secondary effect", these policies have diminished the implementation capacity of the region's governments, thereby further reducing the power of the multiplier.

\section{Interest rate, exchange-rate and balance sheet effects}

As a result of COVID-19, nearly all countries of Latin America and the Caribbean, irrespective of their exchange-rate regime, decided to lower interest rates as a monetary policy (see table 2). In some cases (Brazil, Chile, Costa Rica, El Salvador, Mexico and Paraguay), this stance accentuated the downward trend in base rates that had started before 2020.

\footnotetext{
4 The need for a countercyclical policy in a recession or contraction of economic activity is currently one of the economic-policy issues on which economists of diverse tendencies generally agree. This has not always been the case in Latin America and the Caribbean, as evidenced by the economic policies deployed in response to the various crises faced by the region, such as the debt crisis (1980-1983), the "tequila" crisis (1995) or the Asian crisis (1996-1997).

5 For information on the channel that prioritizes prices and rates of return, see Taylor (1995) and Mishkin (1996); and for further information on the credit channel, see Bernanke and Gertler (1995) and Bernanke, Gertler, and Gilchrist (1999). Trautwein (2000) compares these two views of the monetary policy transmission mechanism.

6 The mainstream economic consensus holds that fiscal policy is a useful countercyclical tool, when expansionary monetary policy is of limited applicability, to expand aggregate demand, including when the monetary policy interest rate nears the zero-bound.
} 
Table 2

Latin America and the Caribbean (27 countries): base interest rates by country and by exchange-rate and monetary regime, January, March and August 2020

\begin{tabular}{|c|c|c|c|}
\hline \multirow[b]{2}{*}{ Exchange-rate regime } & \multicolumn{3}{|c|}{ Monetary regime } \\
\hline & $\begin{array}{l}\text { Exchange-rate anchor } \\
\text { (United States dollars) }\end{array}$ & Monetary aggregate target & Inflation targets \\
\hline Dollarization & $\begin{array}{l}\text { Ecuador (...) } \\
\text { El Salvador }(2.18 ; 4.80 ; 2.32)\end{array}$ & & \\
\hline Currency board & $\begin{array}{l}\text { Eastern Caribbean Currency } \\
\text { Union }(6.5 ; 6.5 ; 2.0)\end{array}$ & & \\
\hline Conventional parity & $\begin{array}{l}\text { Bahamas }(4.0 ; 4.0 ; 4.0) \\
\text { Barbados }(7.0 ; 7.0 ; 2.0) \\
\text { Belize }(11.0 ; 11.0 ; 11.0)\end{array}$ & & \\
\hline Stabilization arrangement & $\begin{array}{l}\text { Guyana }(5.0 ; 5.0 ; 5.0) \\
\text { Trinidad and Tobago }(5.0 ; 3.5 ; 3.5)\end{array}$ & $\begin{array}{l}\text { Bolivia (Plurinational State } \\
\text { of) }(2.75 ; 2.75 ; 2.75)\end{array}$ & Guatemala $(2.75 ; 2.25 ; 1.75)$ \\
\hline Crawling peg regimes & $\begin{array}{l}\text { Honduras }(5.5 ; 4.5 ; 3.75) \\
\text { Nicaragua }(. . .)\end{array}$ & & $\begin{array}{l}\text { Costa Rica }(2.25 ; 1.25 ; 0.75) \\
\text { Dominican Republic } \\
\text { (4.5; 3.5; 3.5) }\end{array}$ \\
\hline Floating & & & $\begin{array}{l}\text { Brazil }(4.5 ; 3.75 ; 2.0) \\
\text { Chile }(1.75 ; 1.00 ; 0.5) \\
\text { Colombia }(4.25 ; 3.75 ; 2.5) \\
\text { Jamaica }(0.5 ; 0.5 ; 0.5) \\
\text { Mexico }(7.25 ; 6.5 ; 4.5) \\
\text { Paraguay }(4.0 ; 3.25 ; 0.75) \\
\text { Peru }(2.25 ; 1.25 ; 0.25) \\
\text { Uruguay }(. . .)\end{array}$ \\
\hline
\end{tabular}

Source: Prepared by the authors, on the basis of International Monetary Fund (IMF), Annual Report on Exchange Arrangements and Exchange Restrictions 2019, Washington, D.C., 2020, and official data.

Note: Figures in parentheses represent base interest rates for January, March and the last available month of 2020. (...) indicates that data is not available.The Eastern Caribbean Currency Union includes Antigua and Barbuda, Dominica, Grenada, Saint Kitts and Nevis, Saint Vincent and the Grenadines, and Saint Lucia.

The monetary policy transmission mechanism depends on the specific combination of exchange-rate and monetary regimes prevailing in each economy. With the exception of the Caribbean economies (Eastern Caribbean Currency Union, Bahamas, Barbados, Belize, Guyana, Trinidad and Tobago), countries with inflation targets (or monetary aggregate targets) and some degree of exchange-rate flexibility (either floating or crawling peg exchange-rate regimes) make up the bulk of the cases considered in table 2 (71\% of all Latin American countries). Taking these countries as an analytical group - particularly those with inflation targets and floating exchange rates - the monetary policy transmission mechanism for an open economy operates through its effect on the local-currency yield curve. A reduction in the domestic monetary policy interest rate makes the slope of this curve steeper, with a consequent depreciation of the exchange rate. ${ }^{7}$

This, in turn, impairs the financial positions of foreign investors in the region whose securities are denominated in local currency. ${ }^{8}$ In the case of sovereign debt, the data reveal an inverse correlation between the trend of sovereign risk as measured by the Emerging Markets Bond Index $(\mathrm{EMBI})^{9}$ and nominal currency depreciation or appreciation. A depreciation (expected or effective) of the local currency is associated with a higher risk perception and can easily cause capital flight (Borio, 2019). Empirical data collected for Latin America display positive and statistically significant correlations between the rates of variation of the $\mathrm{EMBI}$ and those of the nominal exchange rate - for example, Argentina 0.21, Brazil 0.71, Chile 0.46, Colombia 0.64, Mexico 0.63 and Peru 0.39 (see figure 10).

7 See Shin (2014).

8 This assumes that foreign investors' financial positions are unhedged.

9 The emerging market bond index is the key emerging economy risk indicator. It is calculated as the spread between the interest rate that countries pay on dollar-denominated bonds issued by those economies and United States Treasury bonds, which are considered risk-free. The index is based on the behaviour of external debt issued by each country. The less certainty there is that a country will meet its obligations, the higher its $\mathrm{EMBI}$, and vice versa. The minimum rate that an investor would require to invest in a certain country would be equal to the rate on United States Treasury bonds (risk-free) plus the EMBI. See ECLAC (2016). The reasoning here assumes that changes in $\mathrm{EMBl}$ are endogenous to changes in the nominal exchange rate. See Borio (2019). 
Figure 10

Latin America (6 countries): EMBI and nominal exchange rate changes, 2000-2020

A. Argentina ${ }^{a}$

31 January 2006-30 June 2020

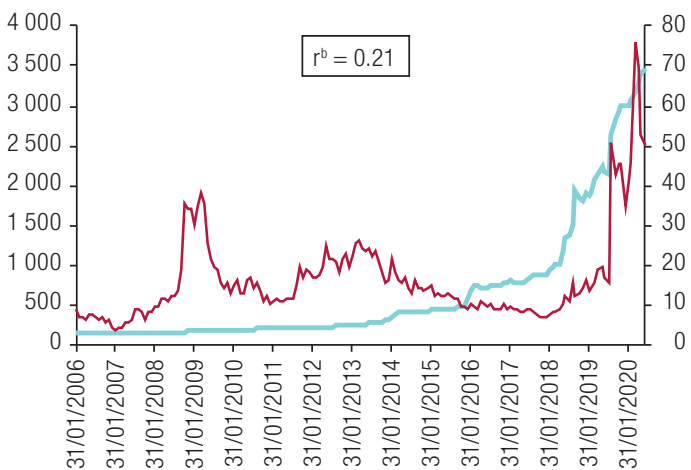

C. Chile

30 January 2004-30 June 2020

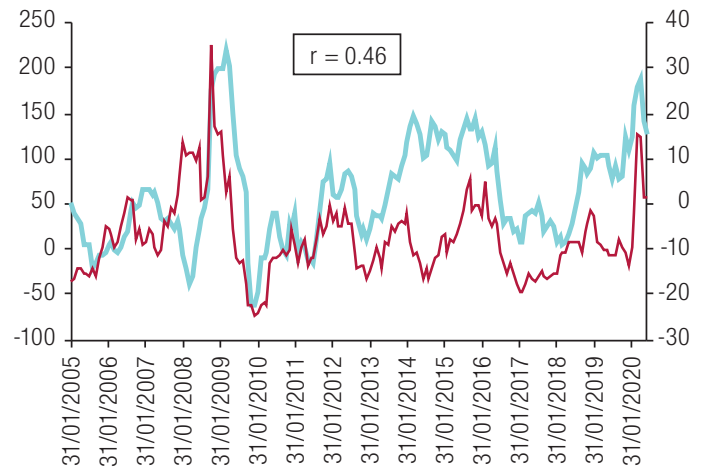

E. Mexico

30 January 2004-30 June 2020

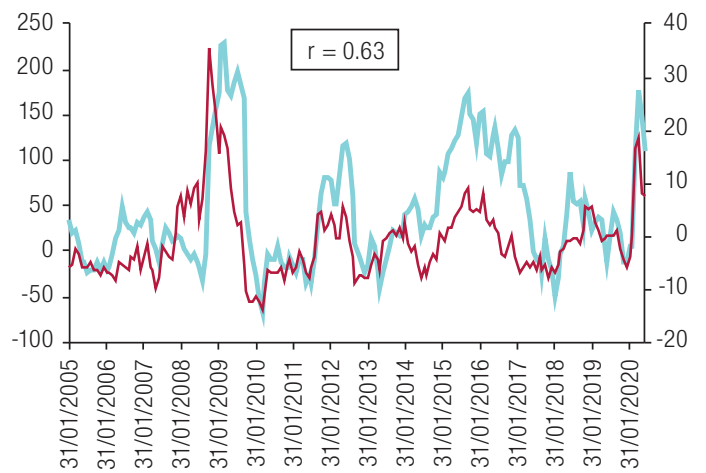

— EMBI (left scale)
B. Brazil

30 January 2004-30 June 2020
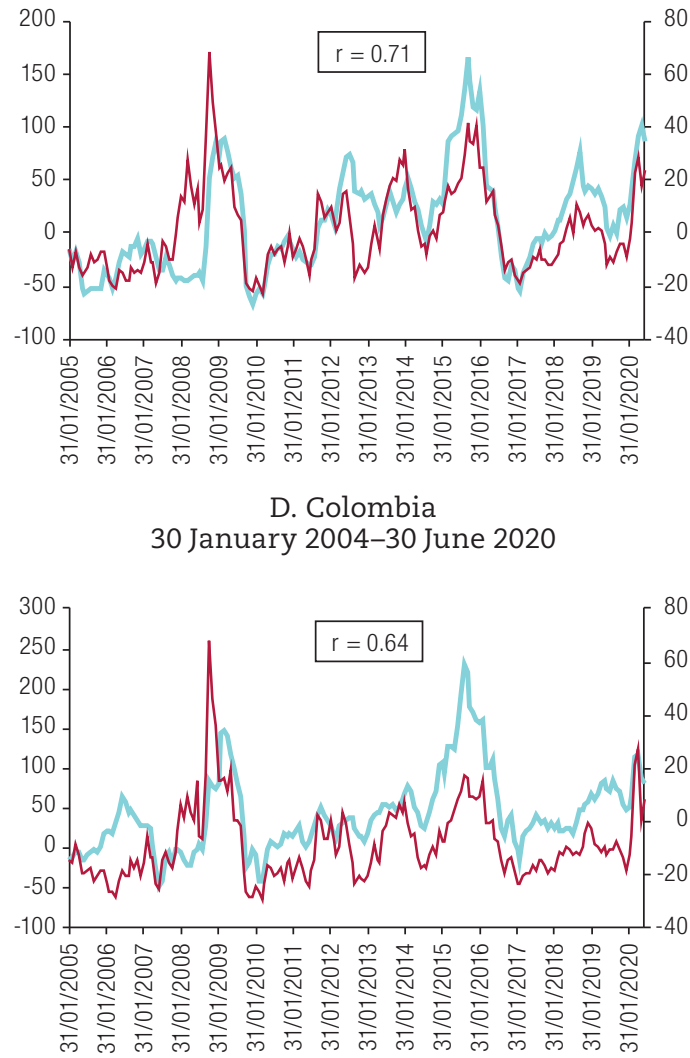

F. Peru

30 January 2004-30 June 2020

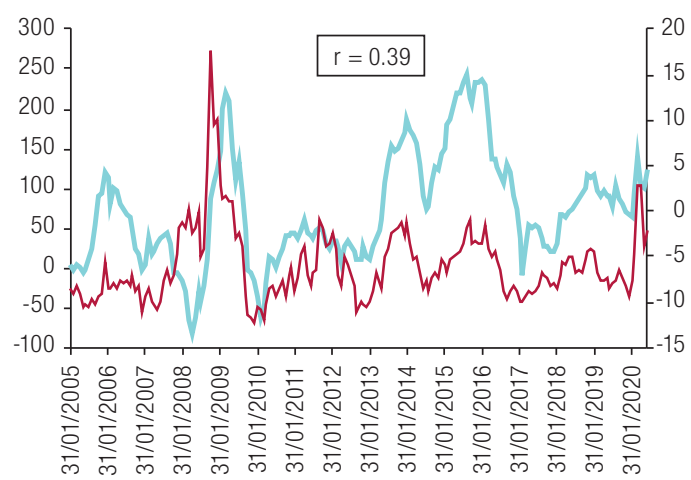

Nominal exchange rate

Source: Prepared by the authors, on the basis of J.P. Morgan, "EMBI Spreads", 2020; and Economic Commission for Latin America and the Caribbean (ECLAC), Economic Survey of Latin America and the Caribbean, 2020 (LC/PUB/2020/12-P), Santiago, 2020.

a In the case of Argentina, the variables are expressed in terms of levels. The right scale measures basis points.

b $r=$ simple correlation coefficient.

Local-currency depreciation also increases the burden of debt service for agents whose liabilities are denominated in foreign currency. In the case of Latin America and the Caribbean, the foreign currency share of the total debt varies by country and sector. Data for 2019 show foreign currency debt-to-GDP 
ratios of $82.1 \%$ in the case of Argentina, 23.9\% in Brazil, 49.2\% in Chile, 28.6\% in Colombia and 26.8\% in Mexico. ${ }^{10}$ Depreciation also increases liabilities by augmenting the local-currency value of the debt stock. Moreover, if the collateral for the debt is also denominated in local currency, then depreciation also reduces asset values.

In short, an interest rate cut not only dampens external financial flows and thus restricts the availability of external liquidity through the mechanisms described here; but it can also generate greater financial fragility. ${ }^{11}$

The intensity of these effects will depend, firstly, on the degree to which the asset and liability currencies are mismatched and, secondly, on the existing debt level. The data indicate that, in developing countries, the corporate sector tends to operate in a mismatch situation, ${ }^{12}$ and that this mismatch has trended higher since 2007. At the same time, the level of external debt in the region has increased in all institutional sectors (government, financial and non-financial corporate sectors, and households). The evidence collected on Latin America between 2006 and 2014 shows an increase in the debt of the non-financial corporate sector and, at the same time, a decrease in foreign-currency coverage (as measured by the ratio of net foreign currency assets to exports, see figure 11), thus signalling an increase in financial fragility in the region. ${ }^{13}$

Figure 11

Latin America: non-financial corporate sector borrowing and corporate sector currency mismatches, 2006-2014

(Billions of dollars and percentages)

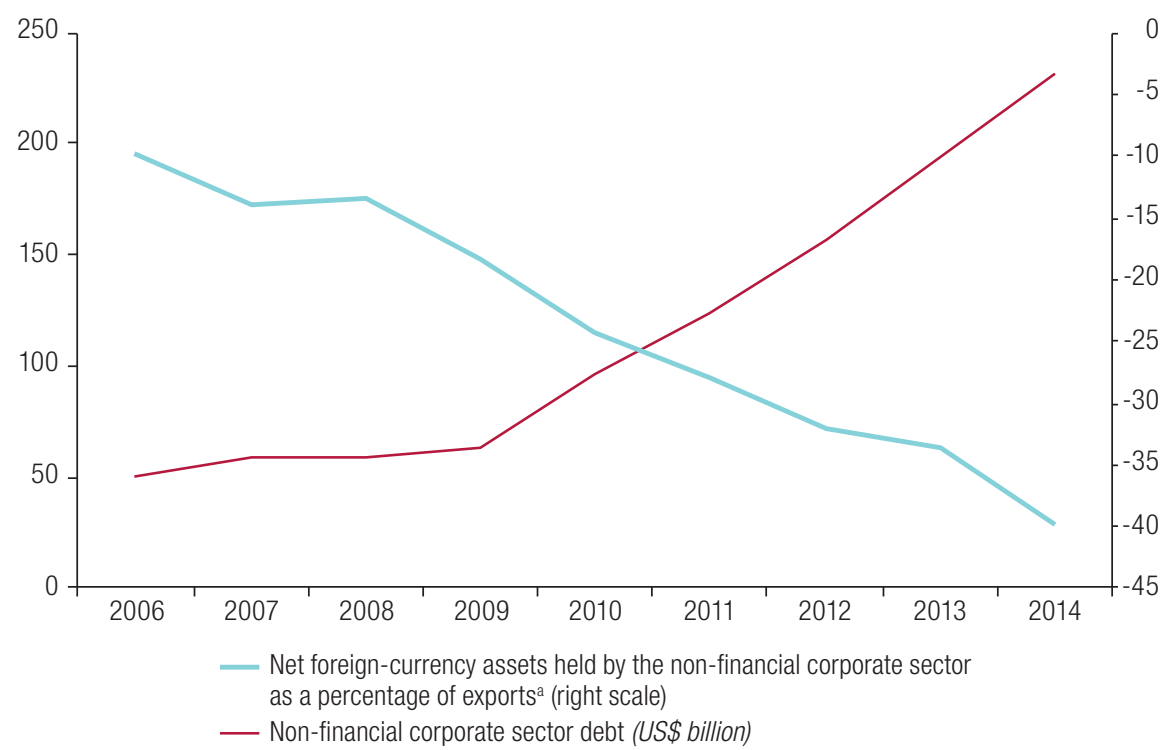

Source: Prepared by the authors on the basis of Bank for International Settlements (BIS), "Debt Statistics", Basle, 2020; and Chui, M., E. Kuruc and Ph. Turner, "Leverage and currency mismatches: Non-financial companies in the emerging markets", The World Economy, vol. 41, No. 12 (Special Issue: Global Trade Policy 2018), 2018 [online] http://wileyonlinelibrary.com/ journal/TWEC.

a Average of the variable for Argentina, the Bolivarian Republic of Venezuela, Brazil, Chile, Colombia, Mexico and Peru.

\footnotetext{
10 In the case of Brazil, this figure underestimates the total debt, since part (equivalent to at least $15 \%$ of GDP) is held by Brazilian nationals living abroad. See ECLAC (2018).

${ }^{11}$ A policy of reserve accumulation through intervention in foreign exchange markets (which in fact has been the countercyclical monetary policy, par excellence, in the case of some of the economies of the region) can have similar effects.

12 Imperfect substitution between currencies worsens arbitrage conditions and consequently makes operations in financial markets with hedged currency positions more difficult. As Shleifer (2000, p.13) notes, arbitrage requires the availability of close substitutes for financial assets. Tropeano (2016) argues that hedging operations depend on the fulfilment of arbitrage conditions.

${ }^{13}$ Non-financial corporate-sector debt has continued to grow in Latin America; and, in the second quarter of 2020, it stood at US\$ 343 billion. See Federal Reserve Bank of St. Louis (2020).
} 


\section{Interest rates and their impact on aggregate demand}

In the context of Latin America and the Caribbean, not only can traditional countercyclical monetary policy generate greater financial instability - through the transmission mechanisms described abovebut it does not necessarily have expansionary effects. Traditional monetary theory states that a cut in the policy interest rate leads to a reduction in the cost of capital. This should elicit an increase in investment and in the demand for consumer durable goods, which, in turn, should boost aggregate demand and, thus, economic growth. However, in the Latin American and Caribbean economies, a large proportion of capital and consumer durable goods are imported, so exchange-rate depreciation raises the cost of capital and consumer durables and thus discourages demand for them.

According to ECLAC (2016), variations in the real exchange rate and in gross fixed capital formation are negatively related (the correlation coefficient is -0.41 ), which indicates that real exchange rate variations affect imports more than exports. ${ }^{14}$ In other words, an appreciation of the real exchange rate is associated with an increase in gross fixed capital formation. Moreover, a depreciation of the nominal and real exchange rate, stemming from a cut in interest rates, is unlikely to affect export performance, owing to the deep productivity gaps that exist, causing competitiveness problems that are not remedied by devaluation. Also, the available data reveal that international goods and services transactions are invoiced in foreign currency, so a change in the nominal exchange rate will not affect their amount in the short term (Borio, 2019).

In the medium and long terms, the exchange-rate impact will depend on both the size of the economies in question and their production structure. For the smaller economies, there is strong empirical evidence that income effects outweigh substitution effects (relative price effects that lead to nominal and real exchange-rate depreciation). ${ }^{15}$ The export performance of these economies depends, fundamentally, on the trend of external demand weighted by the ratio of the income elasticities of exports and imports. ${ }^{16}$

These monetary policy constraints partly explain why peripheral countries, including those that operate inflation targeting monetary regimes, intervene on the foreign-exchange markets, ${ }^{17}$ either through transactions in the spot markets or else through other types of instrument (foreign currency swaps, repos and derivatives). ${ }^{18}$ However, it is important to keep in mind that foreign-exchange interventions require an adequate stock of international reserves; they are also costly and are not always effective.

Lastly, a context of high inequality impedes the central objective of countercyclical monetary policy. An interest rate cut implies an increase in the present value (demand price) of both real assets (whether investment or real estate) and financial assets. ${ }^{19}$ The upward valuation of existing real estate assets in a context of highly unequal income and, especially, wealth, means that the beneficiaries of revaluation are the wealthier groups of society, which are also those with a lower marginal propensity to consume.

A similar argument weakens the strength of the credit approach in the transmission of monetary policy, since it is based on the possibility of obtaining a larger credit flow. This approach alters the cost-of-capital transmission channel by recognizing the existence of information asymmetries between the borrower (for example, a firm) and the lender (such as a bank). In an information asymmetry context,

\footnotetext{
14 The countries included in the sample are Argentina, Brazil, Colombia, Mexico and Peru. This relationship also holds at the national level. Two country-level studies conducted by ECLAC on the determinants of investment in Argentina, Colombia and Peru, find a negative relationship between variations in the real exchange rate and variations in gross fixed capital formation. The nominal exchange rate is the main determinant of the real exchange rate.

15 On this point, see Bernat (2015) and Dvoskin and Feldman (2015).

16 See McCombie and Thirlwall (1994).

17 What the literature calls the "fear of floating" (see Calvo and Reinhart, 2002).

18 See Borio (2019). Mexico and Peru have used repos; Brazil and Mexico have intervened in the future exchange rate; and Colombia and Mexico have intervened in options mechanisms.

${ }^{19}$ In the case of financial assets, the relationship is more direct the longer the maturity of the asset in question.
} 
the least costly way to minimize the risk of default on the lender's claims is to stipulate the transfer or payment of collateral in the event of borrower default. This means that the value of a loan cannot exceed the equity value, that is the sum of the net liquid assets (cash flow minus debt service and principal) and the present value of the collateral. Under this approach, an interest rate cut raises the value of net liquid assets (by reducing debt service) and, also, the present value of the collateral. This in turn reduces information asymmetry by increasing credit and investment. ${ }^{20}$ However, as in the case of the traditional cost channel of monetary policy, this approach fails to take into account existing inequality of income, and prioritizes spending by the high-income groups, which have lower propensity to consume than lower income groups. It is also a supply-driven monetary policy mechanism that fails to take into account aggregate demand. Reducing the information asymmetry between the lender and the borrower does not solve the problem of insufficient aggregate demand.

\section{Fiscal policy transmission mechanisms}

\section{Fiscal policy and the multiplier}

The constraints faced by monetary policy in sustaining economic growth make fiscal policy the natural candidate for responding to the effects of the pandemic and securing the recovery. The Government is the only actor with the mandate and capacity to respond to its immediate and urgent effects.

The main argument for countercyclical fiscal policy is the potential role of the multiplier in boosting aggregate demand and counteracting the slump in growth. Multiplier theory basically holds that, logically, investment spending precedes and, through its impact on income, generates a volume of savings sufficient to "finance" the initial investment spending. These results of the operation of the multiplier do not occur instantaneously, however. On the contrary, they are the outcome of a dynamic process of sequential spending and are only achieved at the end of that process. ${ }^{21}$

The size of the multiplier basically depends on three factors: the degree to which the economy is dependent on the rest of the world, which is reflected in the propensity to import; the distribution of income, which partly determines the propensity to consume; and the tax burden. To express this more rigorously, the multiplier can be formally expressed as

$$
m={\frac{1}{s_{p}+\xi+\tau}}^{22}
$$

\footnotetext{
20 See Trautwein (2000, pp. 162-163).

${ }^{21}$ The multiplier can be explained as follows for a closed economy with no government. The increase in income $(\Delta Y)$ represents a series of investment increments $(\Delta I)$ adjusted for the corresponding propensities to consume $\left(c, c^{2}, c^{3}, \ldots, c^{n}\right)$. That is to say, (1) $\Delta Y=\Delta I+c \Delta I+c^{2} \Delta I+c^{3} \Delta I+c^{4} \Delta I \ldots c^{n} \Delta I$. Factoring out $\Delta I$ gives (2) $\Delta Y=\Delta I\left(1+c+c^{2}+c^{3}+c^{4} \ldots c^{n}\right)$. The expression in parentheses in equation (2) is a geometric series like (3) $\Delta Y=\frac{\Delta I-\Delta I c^{n}}{1-c}=\frac{\Delta I\left(1-c^{n}\right)}{1-c}$. Taking the limit of (2) when $n \rightarrow \infty$, gives (4) $\lim _{n \rightarrow \infty} \Delta Y=\frac{\Delta I}{1-c}$. In the case of an open economy with government, the multiplier is equal to $\frac{1}{(1-c)+m+t^{\prime}}$ where $m$ is the propensity to import and $\tau$ is the share of taxes in GDP. The multiplier formulation adopted in equation (5) follows that of Kalecki. See Kalecki (1954 and 1971) and Laski (2019).

22 Richard Kahn (1931) first introduced the multiplier. Kahn defined the multiplier as the ratio of the increment of total employment associated with a given increment of primary employment in the investment industries (Kahn, 1931; Keynes, 1964, p.115): let $N$ and $N_{2}$ be the total and primary employment in the investment goods industry. Kahn's multiplier is equal to $k^{\prime}=\Delta N / \Delta N_{2}$. On the basis of Kahn's analysis, Keynes developed the investment multiplier $\left(m=k=\frac{\Delta Y}{\Delta l}\right)$, which "tells us that, when there is an increment of aggregate investment, income will increase by an amount which is k times the increment of investment" (Keynes, 1964, p.115). Keynes assumed equality between the employment and investment multiplier although these need not be equal ("there is no reason in general to suppose that $k=k^{\prime}$ "). Keynes made this assumption: $\left(k=k^{\prime} \Leftrightarrow \frac{\Delta Y}{\Delta l}=\frac{\Delta N}{\Delta N_{2}}\right)$. This has influenced most analysis of the multiplier. In the case of Latin America and the Caribbean, there is a clear need to distinguish between the investment and the employment multipliers. Taking into account this distinction in the analysis is outside the scope of this paper but is part of the research activities of the authors.
} 
In this equation, $s_{p}=(1-\alpha)+s_{w} \alpha$ where $s_{p}=$ the average propensity to save; $\alpha=$ the share of wages in GDP; $s_{w}=$ the propensity to save from earned income; $\xi$ = the average propensity to import; and $\tau=$ the average tax burden. Capitalists are assumed to spend all of their income. ${ }^{23}$

For a given level of tax burden $(\bar{\tau})$, the more dependent an economy is on the rest of the world (the greater $\xi$ ) and the lower share of wages in GDP $(\alpha)$ the lower the value of the multiplier will be and the less impact an expansionary fiscal policy will have. Available data for Latin America, for the period following the global financial crisis (2010-2019), show an average tax burden of $15 \%$ of GDP, a wage share of $37 \%$ and an average propensity to import of $20 \%$. With these average values, the multiplier is close to 1 (see table 3 ). ${ }^{24}$

Table 3

Latin America: a first approach to estimate the multiplier

\begin{tabular}{cc}
\hline Multiplier parameters and value & Estimation of the multiplier \\
\hline$s_{w}$ & 0 \\
\hline$\alpha$ & 0.37 \\
\hline$\xi$ & 0.21 \\
\hline$\tau$ & 0.15 \\
\hline$m$ & 1.02 \\
\hline$m_{a s}$ & 1.1 \\
\hline$m_{a c}$ & 0.84 \\
\hline
\end{tabular}

Source: Prepared by the authors, on the basis of Economic Commission for Latin America and the Caribbean (ECLAC), CEPALSTAT [online database] http://estadisticas.cepal.org/cepalstat/portada.html?idioma=english, and official data for 2020 provided by ECLAC and the World Bank.

Note: All the multiplier parameters, with the exception of $\alpha$, are calculated from the average values for 2010-2019. $\alpha$ was computed for the period 2010-2016. In the case of South America, the parameters used are $\alpha=0.40, \xi=0.16$ and $\tau=0.15$. In the case of Central America and Mexico, the parameters used are $\alpha=0.29 ; \xi=0.35$ and $\tau=0.15$.

This has significant implications for fiscal policy. First, if the value of the multiplier is close to 1 , the impact of fiscal policy on aggregate demand depends essentially on an increase in government spending and, in particular, on the increase in public investment, both relative to GDP. This in turn depends on the rate of growth of public investment, the share of public investment in total investment and the share of total investment in GDP.25

Figure 12 reports the results of an exercise to gauge the impact of increased public investment on GDP by combining two hypotheses. The first is the share of public investment in gross fixed capital formation, with values of $10 \%, 20 \%, 30 \%$ and $50 \%$. The second hypothesis refers to the growth rate of public investment, for which it assumes a range of values between $5 \%$ and $30 \%$.

\footnotetext{
23 The multiplier was initially formulated in terms of marginal propensities (i.e. marginal propensity to consume. See Keynes (1964). The marginal propensity of the consumption or the export functions is determined by the slope of that function. The average propensity of the consumption or the export functions is determined by both the slope and the level or position of that function.

24 The tax burden corresponds to the ratio of the tax revenue of the central government to GDP.

25 It is assumed that the share of total gross capital formation in GDP for the period 2010-2019 averages around 20\%.
} 


\section{Figure 12}

Latin America and the Caribbean: contribution of increased public investment to GDP growth (Rate of growth of GDP) a

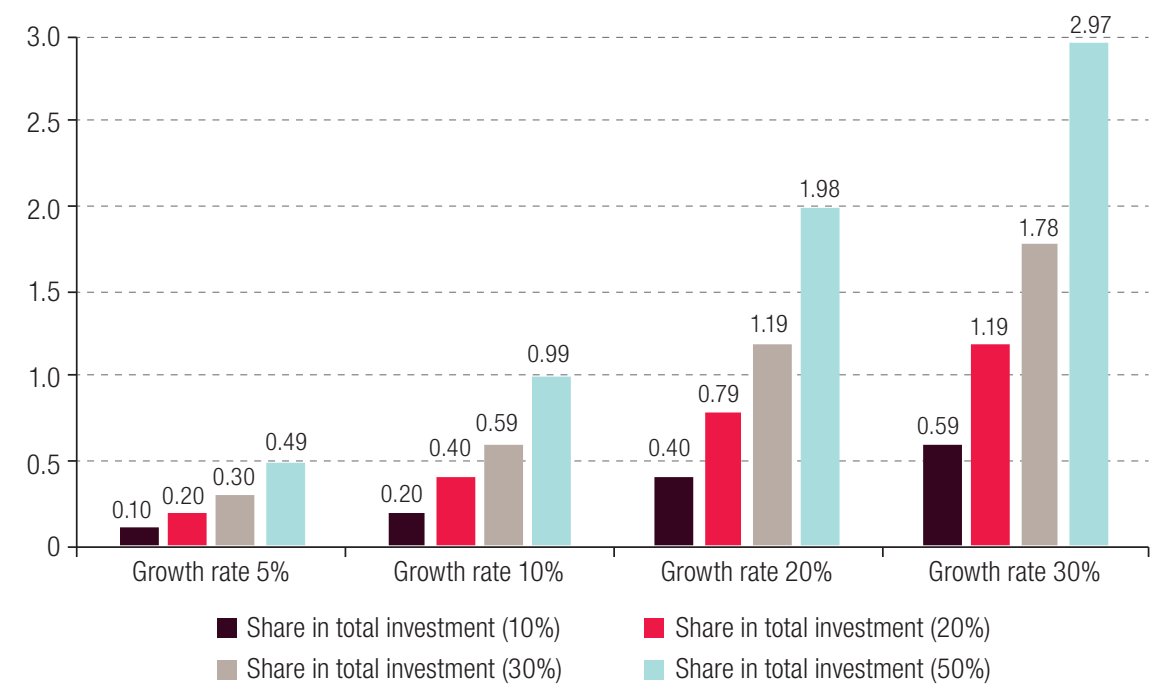

Source:Prepared by the authors on the basis of World Bank, World Development Indicators, Washington, D.C., 2020 [online database] http://data.worldbank.org/data-catalog/world-development-indicators.

a With different public investment shares in the total and investment growth rates.

The results of this calibration exercise reveal how difficult it is to achieve the conditions needed for the increase in public investment to generate GDP growth of more than 1 percentage point. This can occur in the following cases: (i) an initial situation in which the public sector accounts for $20 \%$ of total investment, and public investment growth is on the order of $30 \%$; (ii) an initial situation in which the public sector accounts for $30 \%$ of total investment, and public investment growth is on the order of $20 \%$; (iii) an initial situation in which the public sector accounts for $30 \%$ of total investment, and public investment growth is on the order of 30\%; or (iv) an initial situation in which the public sector accounts for $50 \%$ of total investment, and public investment growth is on the order of $10 \%$; (see figure 12). This means that an expansionary fiscal policy will only have a truly significant impact in countries where the public sector accounts for at least $20 \%$ of the economy's total gross fixed capital formation, and which can decisively increase their investment expenditure by at least $20 \%$ in the short term.

\section{Debt dynamics}

The foregoing analysis also has an impact, in conjunction with other factors, on the dynamics of the debt and its sustainability. This problem can be exemplified with a simple four-equation model. The first equation shows the central government's budget constraint for an open economy in terms of the ratio of public debt to GDP $(d)$. Equation 2 defines the interest rate for the entire debt as a sum of domestic and foreign debt payments weighted by the share of the two components in the total debt $\left(\delta_{d}\right.$ and $\delta_{f}$, respectively). Foreign debt service is assumed to include a surcharge $(p r)$, whose value depends on foreign investors' risk perception.

The third equation defines the multiplier $(m)$, which is the ratio between the GDP growth rate $(\dot{y})$ and the increase in autonomous aggregate demand relative to GDP $\left(\frac{\Delta D_{A}}{G D P}\right)$. The fourth equation establishes a relationship between the GDP growth rate $(\dot{y})$ and the increase in taxes $(\Delta T)$. The fifth equation endogenizes the external debt surcharge as a function of the primary deficit and the variation in the debt/GDP ratio. 


$$
\begin{gathered}
\dot{d}=(r-\dot{y}) d+\frac{(G-T)}{Y} \\
r=\left\{r_{i}\left[\delta_{d}+(1+p r) e \delta_{f}\right]\right\}
\end{gathered}
$$

Where $d=$ ratio of public debt to GDP; $r=$ real interest rate; $r_{i}=$ real domestic interest rate on national-currency debt; $p r$ = surcharge on the domestic interest rate on foreign-currency debt; $\delta_{d}, \delta_{f}=$ shares of domestic and foreign currency debt; $e=$ nominal exchange rate; $\dot{y}=$ growth rate of real GDP; $G=$ total government expenditure; $T=$ tax revenue; $Y=$ level of output.

$m=$ multiplier; $1<m<\infty$

$$
\dot{y}=m \cdot \frac{\Delta D_{A}}{G D P}
$$

$$
\dot{\tau}=\alpha \dot{y}
$$

$\alpha=$ elasticity of tax revenue with respect to changes in the GDP growth rate; $\dot{\tau}=$ rate of growth of tax revenue; $\alpha>0$.

$$
p r=\beta \Delta\left(\frac{G-T}{Y}\right)+\gamma \Delta d \quad \beta+\gamma=1
$$

Current data for Latin America and parameter values that are within the ranges reported in the literature on the subject, can be used to calibrate the potential evolution of public debt in Latin America, as well as other variables of importance for fiscal performance, such as the interest burden of the public debt. On the basis of a simplified version of the above model26 figure 13 calibrates the trend of public debt relative to GDP and the burden of debt interest as a proportion of tax revenues for the period 2019-2027.

Figure 13

Latin America and the Caribbean: calibration exercise for central government debt relative to GDP and interest payments relative to central government revenue, 2019-2027

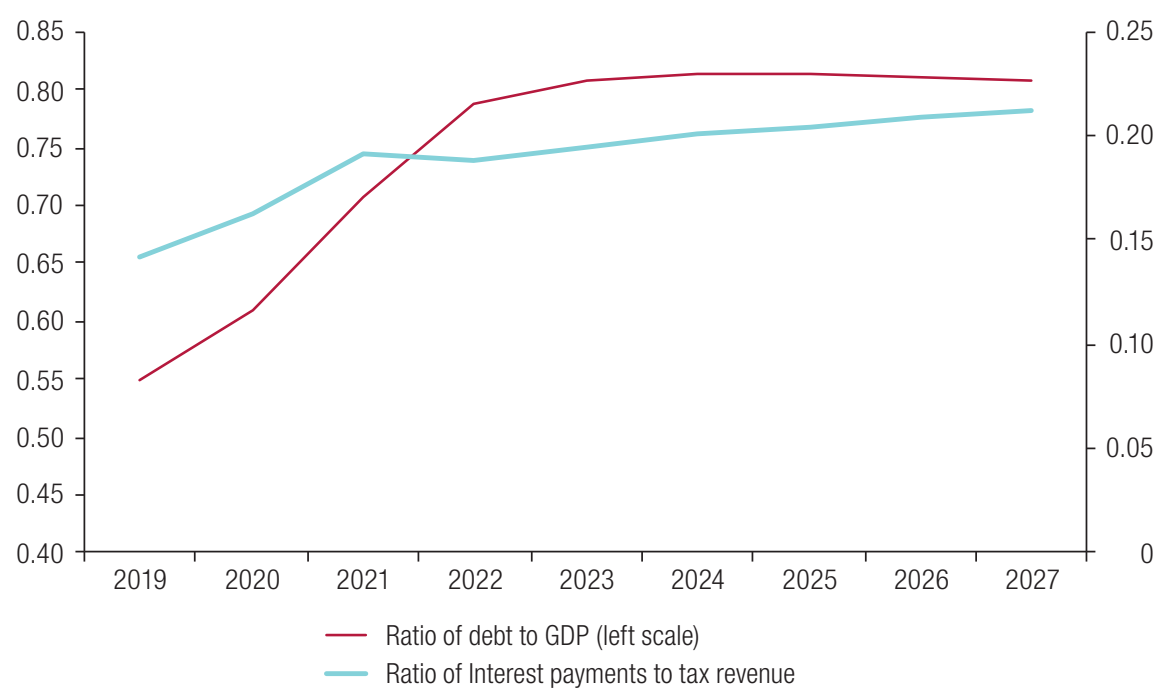

Source: Prepared by the authors on the basis of Economic Commission for Latin America and the Caribbean (ECLAC), EConomic Survey of Latin America and the Caribbean, 2020 (LC/PUB/2020/12-P), Santiago, 2020; ECLAC, Preliminary Overview of The Economies Latin America and the Caribbean, 2020 (LC/PUB.2020/17-P), Santiago, 2020, and World Bank, World Development Indicators, Washington, D.C., 2020 [online database] http://data.worldbank.org/data-catalog/worlddevelopment-indicators.

26 We assume for analytical purposes that $p_{r}=0$ and we do not distinguish between domestic and foreign debt. 
The calibration assumes that the ratios of total central government income and expenditure relative to GDP for Latin America for 2020 are 13.1\% and 18.1\%, respectively (ECLAC, 2020b); ${ }^{27}$ a value of the multiplier of 1 is used for 2019-2022 and 1.5 thereafter, an elasticity of tax collection with respect to GDP of 0.6 and a real interest rate of $4 \%$. It also assumes a contraction in real GDP of $7.7 \%$ in 2020 and rate of growth of $3.7 \%$ for 2021 (ECLAC 2020b). ${ }^{28}$ The rest of the model's values are generated by the workings of the model.

As would be expected, the model's calibration initially reports an increase in debt relative to GDP and an increase in interest payments relative to government revenue.

The debt to GDP ratio begins to stabilize once GDP returns to its pre-COVID-19 level. Within the context of the model's assumption this occurs in 2023, which coincides with the increase in the multiplier from 1 to 1.5. However, debt stabilization is not tantamount to stabilizing the ratio of interest payments to government income. In fact, the model shows that the debt service ratio could continue to increase even after the debt to GDP ratio has stabilized. Policies to stabilize the debt ratio may be necessary to stabilize the debt service ratio, but insufficient on their own. ${ }^{29}$

The results of the model mean that what an economy most needs to do to stabilize its debt position is to boost economic growth. The conclusion drawn from this calibration exercise can also be established, conceptually, from equation (11), which shows that a stable debt/GDP ratio, $\dot{d}=0$, implies that the debt-to-GDP ratio $(d)$ is equal to the ratio between the primary deficit $((G-T) / Y)$ and the difference between the interest rate $(r)$ and growth rate $(\dot{y})$. Formally,

$$
d=\frac{(G-T) / Y}{\left\{r_{i}\left[\delta_{d}+(1+p r) e \delta_{f}\right]-\dot{y}\right\}}
$$

Since both $r_{i}$ and $\dot{y}$ have small values, any change in either of them will have a much larger effect than a variation in the primary deficit $((G-T) / Y)$ (Taylor and others, 2012). The countries of the region do not control the term $r_{i}\left[\delta_{d}+(1+p r)\left(e \delta_{f}\right)\right]$. This is essentially due to the existence of a risk premium $(p r)$, so the only way to significantly reduce the steady-state value of the debt/GDP ratio is to increase the growth rate.

However, this increase will only be sustainable in the long term if capacity building (true competitiveness) makes it possible to alter the income elasticities of exports and imports, and thus raise the growth rate while maintaining external balance. The variable $G$ and its effect on $\dot{y}$ are therefore the main factors determining the fiscal sustainability of the policy response to the pandemic. However, as suggested in the following section, the impact of $G$ on $\varepsilon / \pi$ is what ultimately links short-term recovery with long-term reconstruction and establishes the conditions that allow for an expansionary fiscal policy that is sustained over time. Consequently, the ultimate determinant of fiscal sustainability, external sustainability and the growth path of a peripheral economy depends on these variables and on the trend of the debt-to-GDP ratio, rather than on deficit reduction per se.

Stabilizing the debt service ratios may require, in addition to policies to boost growth, a set of consistent exchange rate and monetary policies. ${ }^{30}$ However, the leverage to stabilize debt service ratios also depends on external factors outside the control (whether partial or total) of domestic authorities, such as for example changes in the risk premium ( $p r)$ and also in international rates of interest.

\footnotetext{
27 This refers to the period January-September 2020.

28 The increase in autonomous demand is adjusted, so it translates into 3.7\% GDP growth for 2021 .

29 This has obvious implications for economic development. Financial stability does not guarantee the required policy space to pursue fiscal policies for economic development, as some of the fiscal resources will be earmarked for debt service.

${ }^{30}$ A reduction in domestic interest rates may also reduce domestic currency denominated debt service payments and increase foreign currency denominated debt service payments, owing to nominal exchange rate depreciation.
} 


\section{Fiscal policy and investment in structural change in the face of the pandemic}

The previous section suggests that the region's institutional and structural characteristics impose considerable constraints on the functioning and effectiveness of countercyclical policy. The conclusion that emerges from the analysis is that a structural change is required to make such a policy more effective.

This idea is exemplified by a model that shows how increasing returns to technological learning and fiscal policy combine with the external constraint to generate different scenarios in a peripheral economy hit by pandemic shocks. Two growth rates are defined: the growth rate that represents the economy's long-term equilibrium and is compatible with the external constraint; and the effective growth rate, which is the actual rate and is not necessarily the same as the long-term equilibrium rate. While the most correct way to assess the external constraint involves considering the basic balance of payments (current account and long-term capital movements), it will be assumed that external balance is achieved when the trade balance is equal to zero. The exclusion of long-term financial flows does not change the analysis substantially. In general, the pandemic has had a greater effect on the current account than on long-term flows.

The effective growth rate of the peripheral economy $y_{p}$ has several components that will be divided into two groups: the growth rate of the centre $y_{c}$ multiplied by a factor that depends on the income elasticity of exports $\varepsilon$, the income elasticity of imports $\pi$ and the relative weight of imports and exports in GDP; and the rate of increase of autonomous spending in GDP, multiplied by a factor that depends on the shares of autonomous expenditure and imports in GDP, and the income elasticity of imports. As argued in the previous section, the effectiveness of autonomous expenditure also depends on the functional distribution of income. For reasons of analytical simplicity, the model in this section excludes this component.

In figure 14, the TEC curve represents the effective growth rate; and the intercept of this curve changes ceteris paribus with variations in the autonomous expenditure of the periphery. The higher the income elasticity of imports and the larger the import share of GDP, the lower the value of the multiplier of incremental autonomous spending (including fiscal expenditure). Thus, production structures that are not very diversified and have less dynamic international demand tend to have a lower-value multiplier, as discussed above. ${ }^{31}$

The (long-term) growth rate with external balance of the periphery $y_{P}^{E}$ is a function exclusively of the relationship between the income elasticity of exports and imports $\left(\frac{\varepsilon}{\pi}\right)$, multiplied by the growth rate of the centre $y_{c}{ }^{32}$ Formally, this is called Thirlwall's Law, where

$$
y_{P}^{E}=\frac{\varepsilon}{\pi} y_{c}
$$

The rate at which the periphery can grow by keeping the net long-term trade balance at zero, for each growth rate in the centre, is represented by the $\mathrm{CC}$ line. This equation assumes that the real exchange rate is stable.

Figure 14 shows the different growth rates, the effective peripheral growth rate (TEC) and the long-term external equilibrium rate (CC). The growth rate of the centre is shown as a vertical line, because it is determined exogenously to the model. The elasticities depend on the production structure

\footnotetext{
${ }^{31}$ The quotient $\frac{\alpha}{1-\beta_{2} \pi}$ is the multiplier of the increase in autonomous expenditure (the components of which include public investment and that derived from "animal spirits"). For a study of the multiplier in a model with an external constraint on growth, see McCombie and Thirlwall (1994, chapter 9).

32 For a review of these models, see Blecker and Setterfield (2019, chapter 12); see also ECLAC (2012).
} 
of the periphery, which, by nature, cannot change very much in the short term. The less technologyintensive and less diversified this structure is, the smaller the ratio $\left(\frac{\varepsilon}{\pi}\right)$ and the flatter the CC line. To make this curve steeper, it is necessary to create "authentic competitiveness" (as opposed to "spurious competitiveness", in the words of Fernando Fajnzylber); in other words, a competitiveness that is based on technological capacities and on narrowing of the technology gap between the centre and the periphery. At point A, the TEC and CC curves intersect, so the effective and long-term equilibrium rates coincide.

Figure 14

Conservative fiscal policy: investment collapse and loss of capacities

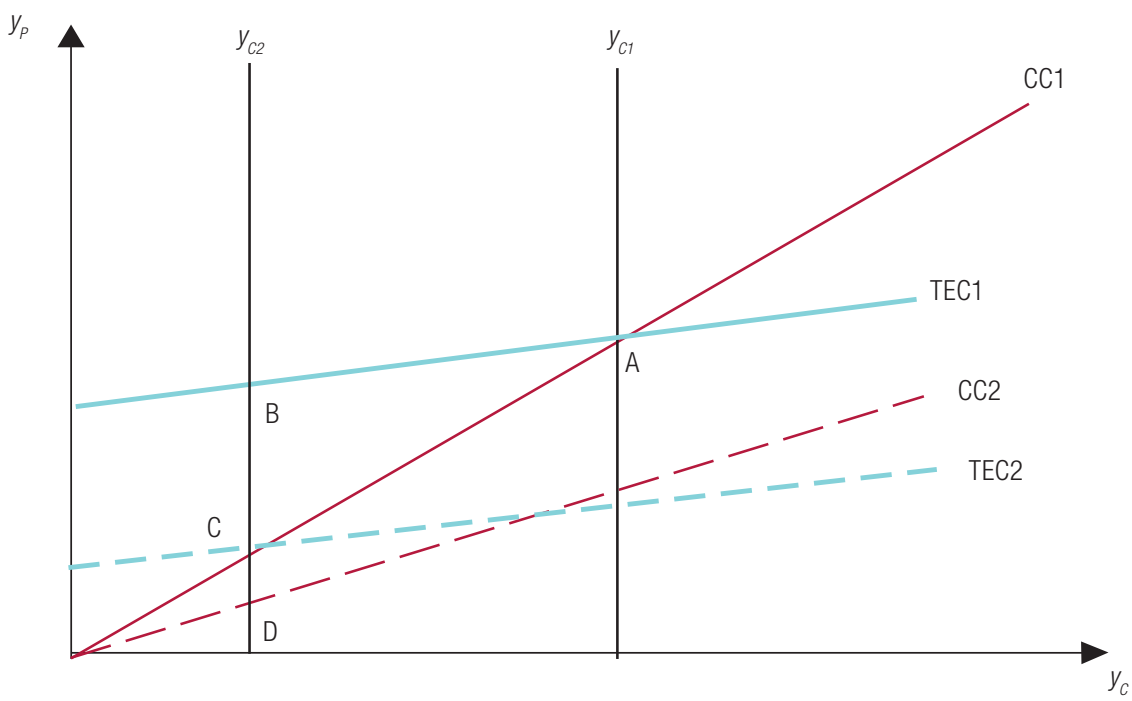

Source: Prepared by the authors.
Note: $\mathrm{CC}$ is the growth rate with current account balance, CC: $y_{P}^{E}=\frac{\varepsilon}{\pi} y_{c}$. TEC is the effective growth rate $y_{P}=\frac{\alpha a+\beta_{1}\left(\varepsilon y_{c}\right)}{1-\beta_{2} \pi}$, where $\alpha \equiv A / Y, \beta_{1} \equiv X / Y$ and $\beta_{2} \equiv Q M / Y . A$ is autonomous expenditure; $X$, exports; $M$, imports, and $Y$, GDP, all in real terms.

It is assumed that the pandemic causes a disruption in the world economy, which shifts the centre's effective growth rate to the left. Consequently, the effective rate of growth of the economy moves from point A to point B in figure 14. However, at the same time, domestic demand contracts as a result of reduced aggregate demand, particularly in investment and consumption spending, and the job losses associated with lockdown. The contraction in investment and consumption more than offsets the positive effect of the reduction in the average propensity to import $\left(\frac{M}{Y}\right)$. This reasoning is consistent with the stylized facts that have been observed in the region's countries: contraction of investment, consumption and imports of goods and services (ECLAC, 2020a).

The TEC1 curve thus shifts down as a result of the contraction of both domestic and external demand. Depending on the speed with which exports decline (owing to the contraction in global GDP) relative to imports (owing to the fall in national GDP), the economy's external position with respect to the rest of the world could either improve or deteriorate. Available data on the region show that, in the smaller economies, including those of the Central American isthmus and the Caribbean, the contractionary effect on external demand through exports generally outweighs the reduction in imports that results from falling domestic demand. According to the International Monetary Fund, between 2019 and 2020 the current account deficit of the countries of the Central American isthmus is likely to increase on average from $1.7 \%$ to $3.3 \%$ of GDP, while in the Caribbean it would go from $8 \%$ to $18 \%$ of GDP (IMF, 2020b). For the rest of the economies in the region, evidence points to an improvement in the current accounts of Brazil, Chile, Colombia, Mexico, Peru and the Plurinational State of Bolivia. 
In the long term, the new equilibrium point will be $\mathrm{C}$. Autonomous expenditure would have to move from TEC1 to TEC2 (the dashed blue line) so that the effective exchange rate and external equilibrium coincide in the new situation created by the pandemic, and equilibrium in the trade balance is thus restored. The path of return to external balance (the movement from TEC1 to TEC2) requires autonomous expenditure to be reduced. This movement is explained by factors associated with domestic and external demand. As noted above, in a crisis situation, with significant supply constraints in some key sectors, a general increase in idle capacity and very high uncertainty — such as that generated by the pandemic crisis - capitalists' "animal spirits" collapse, and consumer spending contracts. The increase in idle capacity dampens expectations for the profitability of new investments. In this context, the effects of aggregate supply and demand are mutually reinforcing and create a negative interaction between the multiplier and the accelerator: while the contraction of autonomous aggregate demand reduces both output and income owing to the multiplier effect, the expectation of lower future consumption reduces investments owing to the accelerator effect.

In general, this contraction in demand is not offset by increased public spending - as was evident during the first year of the pandemic. Public expenditure has been mainly targeted on repair measures and on responding to the urgency of the pandemic, rather than on actions aimed at stimulating the economies (although, of course, compensatory measures helped to cushion the fall in autonomous spending). Naturally, the contraction will be deeper, or the recovery slower, if governments adopt procyclical policies and view the growing fiscal deficit with alarm, or seek premature "consolidation" of the fiscal outcome. In addition, the slide in investment will be aggravated if governments use monetary policy more intensively. As explained above, not only is monetary policy less effective than fiscal policy, but, in a context of close international financial integration, it can become counterproductive. Capital outflows resulting from an expansionary monetary policy can heighten exchange rate volatility and increase the cost of borrowing in international credit markets. Ultimately, it reinforces uncertainty and the fall in aggregate demand and, with it, the decline in the local economy's expected profit rate.

The story does not end here, however. The retreat of investment implies the loss of technological and productive capacities, which in turn entails a loss of structural competitiveness and, therefore, a fall in the ratio between the income elasticities of exports and imports. The CC curve becomes flatter when the $\left(\frac{\varepsilon}{\pi}\right)$ ratio falls. The curve representing the external balance is no longer CC1 but CC2 (the dashed red line). In this framework, unless measures are adopted to mitigate the decline in technological and productive capacities, the new point of external balance will be $D$, and not $C$, in figure 14 . This means that the peripheral economy may find it hard to reduce its trade deficit, even after cutting autonomous expenditure and reaching point $\mathrm{C}$. In such a case, a new adjustment will be needed to establish equilibrium (in other words, a further downward shift in the TEC curve, not drawn). This tends to form a negative spiral of declining growth and loss of capacities (both TEC and CC shift downwards, one curve chasing the other, in a vicious circle). Even if the process is not explosive, the final equilibrium outcome (point D) implies levels of aggregate demand, income distribution and productive capacities that are even less favourable than those resulting from the initial impact of the pandemic.

What happens if the government adopts a countercyclical policy to support aggregate demand? This means that the TEC curve does not shift downwards (or at least not as drastically), as shown in figure 15. To simplify the interpretation of the graph, one can imagine that the government's fiscal policy (now strongly expansionary) manages to keep the TEC curve in place (TEC1). To achieve this, autonomous public expenditure would have to make up for the deterioration of business "animal spirits" and the retraction of private consumption. Furthermore, based on the analysis in the previous section, this countercyclical policy could - or rather, should - include an income redistribution component in order to raise the marginal propensity to consume and thus strengthen the multiplier. 


\section{Figure 15}

Fiscal policy combined with industrial policy: capacity building, closing gaps and sustaining aggregate demand

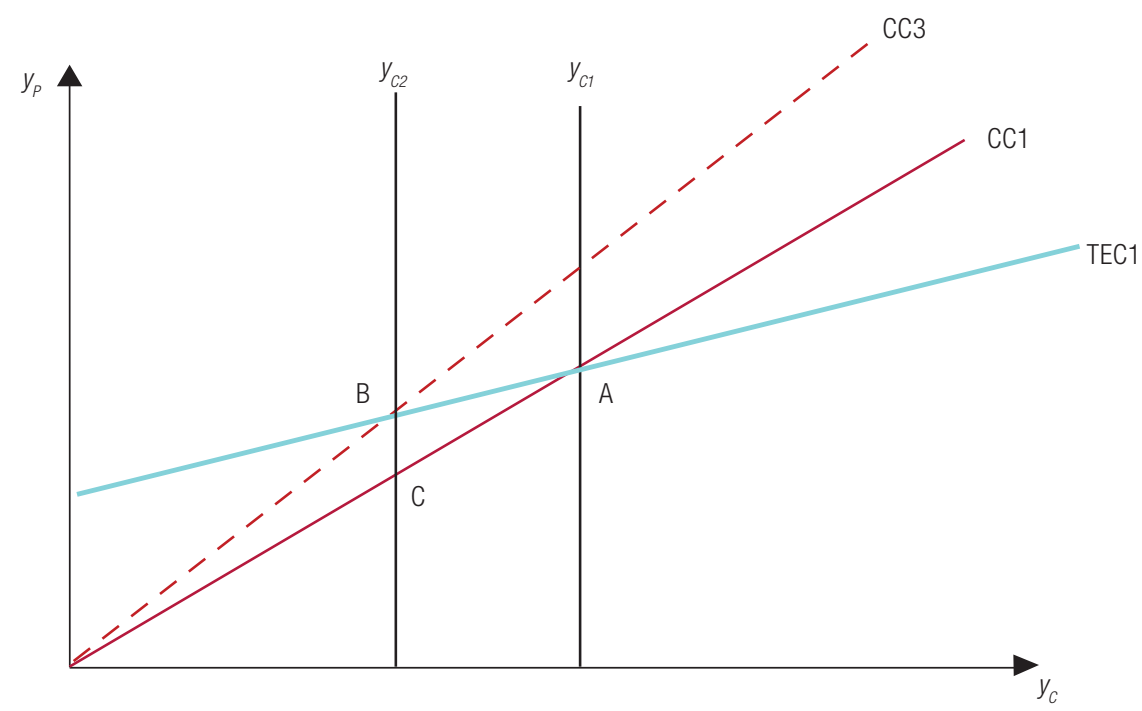

Source: Prepared by the authors.
Note: CC is the growth rate with current account balance, CC: $y_{P}^{E}=\frac{\varepsilon}{\pi} y_{c}$. TEC is the effective growth rate $y_{P}=\frac{\alpha a+\beta_{1}\left(\varepsilon y_{c}\right)}{1-\beta_{2} \pi}$, where, $\alpha \equiv A / Y, \beta_{1} \equiv X / Y$ and $\beta_{2} \equiv Q M / Y$. $A$ is autonomous expenditure; $X$, exports; $M$, imports, and $Y$, GDP, all in real terms.

However, the TEC curve is not sustainable in the long term if the position of the CC curve is not changed to restore the trade balance. Public spending should therefore combine emergency measures to combat poverty and unemployment and redistribute income with an increase in the levels of investment in technology and skills, which aim both to raise $\varepsilon$ and to reduce $\pi$-and thus make the CC curve steeper. A reduction in $\pi$ would also help to make room for the intensity of countercyclical policy by increasing the value of the multiplier (see previous section).

In this case, external balance is achieved by shifting the CC curve from CC1 to CC3 (the dashed red line in figure 15), not by lowering the TEC curve. For simplicity, it has been assumed that the new CC3 curve cuts the TEC1 curve at point B; but the equilibrium is most likely reached at a slightly lower point, between B and C. It would be very difficult for public investment (and fiscal policy in general) to fully compensate for the full impact of the pandemic. Point $B$ is lower than starting point $A$, but higher than point $D$, which represented the final balance without fiscal policies to sustain investment and capacities.

While such a strategy implies a determination to support sustained technology expenditure and the structural transformation of the economy, it also means accepting a current account deficit for a certain period of time. In this connection, the international cooperation and more concessional financing of deficits that could emerge in peripheral economies are particularly important in helping peripheral economies recover rapidly from the pandemic. International support is especially necessary if there is already a complicated external situation owing to previous indebtedness and a large deficit on the income account. Moreover, the recovery can benefit the central economies themselves, since it stimulates the recovery of global aggregate demand.

This support does not depend exclusively on greater access to external financing, which may be amply available on international credit markets, especially in the context of the expansionary monetary policies implemented in the central economies. It should also incorporate, a greater acceptance by the central countries of peripheral countries introducing measures to help target this financing towards 
their long-term objectives -in particular, structural change aimed at accelerating growth in a manner consistent with long-term external balance. As discussed below, this means not only a greater acceptance of industrial and technological policies in peripheral countries - or at least a "halt" to retaliation - but also regulation of the intensity and use of international capital flows which, in small and open economies such as those of Latin America and the Caribbean, can have both disruptive and constructive effects, as Carlos Díaz Alejandro (1984) predicted.

The foregoing analysis illustrates the importance of the intensity and targeting of fiscal measures during a pandemic. Recovery efforts need to go hand-in-hand with an industrial policy that redefines competitiveness and capacities at the periphery, promotes export diversification (preferably), and substitutes for imports (if appropriate) in a crisis context. As noted below, the conditions that enable such a strategy, including the implementation of an expansionary fiscal policy over a longer period of time than usual, relate to the way the economies in question access international financial markets.

\section{Conclusions}

The pandemic is affecting economies that already had a weak structural platform for growth. The Latin American and Caribbean region has lagged behind the developed economies and, especially, other developing economies that have introduced profound changes in their specialization patterns and international engagement in recent decades. The combination of industrial and macroeconomic policies adopted in several Asian countries, which fostered the development of local production and technological capacities and reduced their exposure to global liquidity cycles, was not adopted by Latin American countries. This is an unresolved issue in our region.

Monetary policies have proven inefficient in both developed and developing countries alike: and there is a consensus on the need to make greater use of fiscal policies. In the Latin American economies, fiscal policies are hampered by the low value of fiscal expenditure multipliers and, depending on the circumstances, by the external constraint on growth. This reflects the heterogeneity of production structures, the existence of a wide spectrum of activities with significant productivity gaps, and generally weak backward and forward linkages. As a consequence of this structural situation, a significant fraction of aggregate demand "leaks" out of domestic circulation, without global demand generating compensatory effects of the same magnitude in the domestic economy.

What response should be made to a scenario as complex as that generated by the pandemic? The lessons drawn from the foregoing analysis are as follows: first, to have a significant impact on aggregate demand, the expansionary fiscal policies adopted in the region must be on a large scale; second, investment must have a very large share in the total fiscal effort; and lastly, investment must be targeted towards the creation of capacities or "true competitiveness", based on technology and diversification, to avoid external imbalances detracting from the momentum of growth and forcing a retreat towards a policy of austerity. Regional integration policies can support industrial policy in the search for a new production pattern. Progressive tax policies are important to ensure that the public debt/GDP ratio follows a sustainable path that is compatible with the goals of reducing inequality.

To avoid compromising macroeconomic stability and, thus impairing the positive effects of industrial policy on productivity and competitiveness, it is essential to have a stable real exchange rate, which avoids volatile trajectories that move with the swings of global liquidity and the pernicious cycles of external debt - exchange-rate appreciation - contractionary devaluation. In an increasingly volatile world, in which very short-term capital movements predominate (along with their effects on the level of uncertainty), keeping the capital account open is an invitation for the vagaries of financial markets and international commodity prices, currency speculation and liquidity cycles to compromise the 
diversification of the production base, the change in the elasticities of trade and the multipliers. There is a seemingly paradoxical situation: long-term policies aimed at changing the production base and creating linkages are the key to making short-term macroeconomic policies more effective. Structural change and macroeconomic stability interact virtuously in the long run.

Despite these difficulties, the crisis also provides an opportunity to overcome the constraints imposed on political action, especially the ideological barriers that prevented giving greater weight to fiscal (expansionary) policy in the toolkit for responding to recessions such as those caused by the pandemic. What this article attempts to convey is that the response to the short-term emergency must involve investments that overcome long-term obstacles, basically the external constraint.

\section{Bibliography}

Bernanke, B. and M. Gertler (1995), "Inside the black box: The credit channel of monetary policy transmission", Journal of Economic Perspectives, vol. 9, No. 4, National Bureau of Economic Research (NBER).

Bernanke, B., M. Gertler and S. Gilchrist (1999), "The financial accelerator in a quantitative business cycle framework", Handbook of Macroeconomics, J. Taylor and M. Woodford (eds.), Amsterdam, North Holland.

Bernat, G. (2015), "Tipo de cambio real y comercio exterior en América del Sur: un abordaje sectorial", Estructura productiva y política macroeconómica: enfoques heterodoxos desde América Latina, A. Bárcena, A. Prado and M. Abeles (eds.), ECLAC Books, No. 138 (LC/G.2653-P), Santiago, Economic Commission for Latin America and the Caribbean (ECLAC).

BIS (Bank for International Settlements) (2020), "Debt Statistics", Basel.

Blecker, R. and M. Setterfield (2019), Heterodox Macroeconomics: Models of Demand, Distribution and Growth, Cheltenham, Edward Elgar.

Borio, C. (2019), "Monetary policy frameworks in EMEs: inflation targeting, the exchange rate and financial stability", Annual Economic Report 2019, Geneva, Bank for International Settlements (BIS) [online] https:// www.bis.org/publ/arpdf/ar2019e2.pdf.

Calvo, G. and C. Reinhart (2002), "Fear of floating", The Quarterly Journal of Economics, vol. 117, No. 2.

Chui, M., E. Kuruc and Ph. Turner (2018), "Leverage and currency mismatches: Non-financial companies in the emerging markets", The World Economy, vol. 41, No. 12 (Special Issue: Global Trade Policy 2018) [online] http://wileyonlinelibrary.com/journal/TWEC.

Díaz Alejandro, C. (1984), "Latin American debt: I don't think we are in Kansas anymore", Brookings Papers on Economic Activity, No. 2.

Dvoskin, A. and G. Feldman (2015), "Política cambiaria, distribución del ingreso y estructura productiva", Estructura productiva y política macroeconómica: enfoques heterodoxos desde América Latina, A. Bárcena, A. Prado and M. Abeles (eds.), ECLAC Books, No. 138 (LC/G.2653-P), Santiago, Economic Commission for Lain America and the Caribbean (ECLAC).

Federal Reserve Bank of St. Louis (2020), Federal Reserve Economic Data (FRED) [online] https://fred. stlouisfed.org/.

ECLAC (Economic Commission for Latin America and the Caribbean) (2020a), Economic Survey of Latin America and the Caribbean, 2020 (LC/PUB/2020/12-P), Santiago.

- (2020b), Preliminary Overview of The Economies Latin America and the Caribbean, 2020 (LC/PUB.2020/17-P), Santiago.

(2018), Economic Survey of Latin America and the Caribbean, 2018 (LC/PUB.2018/17-P), Santiago.

(2016), Horizons 2030: Equality at the Centre of Sustainable Development (LC/G.2660/Rev.1), Santiago. (2012), Structural Change for Equality: An Integrated Approach to Development (LC/G.2524(SES.34/3)), Santiago.

IMF (International Monetary Fund) (2020a), Annual Report on Exchange Arrangements and Exchange Restrictions 2019, Washington, D.C.

(2020b), World Economic Outlook: A Long and Difficult Ascent, Washington, D.C., October.

Kalecki, M. (1971), Selected Essays on the Dynamics of the Capitalist Economy, 1933-1970, Cambridge, Cambridge University Press.

(1954), Theory of Economic Dynamics, London, George Allen \& Unwin. 
Kahn, R. (1931), "The relation of home investment to unemployment", The Economic Journal, vol. 41, No. 162, June.

Keynes, J. M. (1964), The General Theory of Employment, Interest, and Money, New York, HBJ.

Laski, K. (2019), Lectures in Macroeconomics, New York, Oxford University Press.

McCombie, J. S. and A. P. Thirlwall (1994), Economic Growth and the Balance-of-Payments Constraint, Basingstoke, MacMillan.

Mishkin, F. (1996), "The channels of monetary transmission: Lessons for monetary policy", NBER Working Paper, No. 5464, National Bureau of Economic Research (NBER).

Shin, H. S. (2014), "The second phase of global liquidity and its impact on emerging economies", Volatile Capital Flows in Korea, K. Chung and others (eds.), New York, Palgrave Macmillan.

Shleifer, A. (2000), Inefficient Markets, New York, Oxford University Press.

Taylor, J. B. (1995), "The monetary transmission mechanism: An empirical framework", Journal of Economic Perspectives, vol. 9, No. 4, American Economic Association.

Taylor, L. and others (2012), "Fiscal deficits, economic growth and government debt in the USA", Cambridge Journal of Economics, vol. 36, No. 1, Oxford University Press.

Trautwein, H. (2000), "The credit view, old and new", Journal of Economic Surveys, vol. 14, No. 2.

Tropeano, D. (2016), "Hedging, arbitrage and the financialization of commodity markets", International Journal of Political Economy, vol. 45, No. 3.

World Bank (2020), World Development Indicators, Washington, D.C. [online database] http://data.worldbank. org/data-catalog/world-development-indicators. 